\title{
Ecology and evolution of plant diversity in the endangered campo rupestre: a neglected conservation priority
}

\author{
Fernando A. O. Silveira • Daniel Negreiros - Newton P. U. Barbosa • Elise Buisson • Flávio F. Carmo • \\ Daniel W. Carstensen • Abel A. Conceição • Tatiana G. Cornelissen • Lívia Echternacht • \\ G. Wilson Fernandes • Queila S. Garcia • Tadeu J. Guerra • Claudia M. Jacobi • José P. Lemos-Filho • \\ Soizig Le Stradic • Leonor Patrícia C. Morellato • Frederico S. Neves • Rafael S. Oliveira • \\ Carlos E. Schaefer • Pedro L. Viana $\cdot$ Hans Lambers
}

Received: 9 April 2015 / Accepted: 7 August 2015 / Published online: 18 August 2015

(C) Springer International Publishing Switzerland 2015

\begin{abstract}
Background Botanists, ecologists and evolutionary biologists are familiar with the astonishing species richness and endemism of the fynbos of the Cape Floristic Region and the ancient and unique flora of the kwongkan of south-western Australia. These regions represent old climatically-buffered infertile landscapes
\end{abstract}

Responsible Editor: Philippe Hinsinger.

Electronic supplementary material The online version of this article (doi:10.1007/s11104-015-2637-8) contains supplementary material, which is available to authorized users.

F. A. O. Silveira $(\bowtie) \cdot$ Q. S. Garcia • T. J. Guerra •

J. P. Lemos-Filho

Departamento de Botânica, Universidade Federal de Minas Gerais, Belo Horizonte, Brazil

e-mail: faosilveira@icb.ufmg.br

D. Negreiros • N. P. U. Barbosa $•$ G. W. Fernandes •

C. M. Jacobi $\cdot$ S. Le Stradic $\cdot$ F. S. Neves

Departamento de Biologia Geral, Universidade Federal de Minas Gerais, Belo Horizonte, Brazil

E. Buisson · S. Le Stradic

Université d'Avignon et desPays de Vaucluse, Institut

Méditerranéen de Biodiversité et d'Ecologie - UMR CNRS IRD

Aix-Marseille Université, Marseille, France

F. F. Carmo

Instituto Prístino, Belo Horizonte, Brazil

D. W. Carstensen - L. P. C. Morellato

Departamento de Botânica, Universidade Estadual Paulista,

UNESP, Araraquara, Brazil
(OCBILs) that are the basis of a general hypothesis to explain their richness and endemism. However, few ecologists are familiar with the campo rupestre of central and eastern Brazil, an extremely old mountaintop ecosystem that is both a museum of ancient lineages and a cradle of continuing diversification of endemic lineages.

\section{A. A. Conceição}

Departamento de Ciências Biológicas, Universidade Estadual de Feira de Santana, Feira de Santana, Brazil

T. G. Cornelissen

Departamento de Ciências Naturais, Universidade Federal de São João Del-Rei, São João del Rei, Brazil

L. Echternacht

Departamento de Biologia, Universidade Federal de Uberlândia, Uberlândia, Brazil

G. W. Fernandes

Department of Biology, Stanford University, Stanford, CA 94305, USA

S. Le Stradic

Gembloux Agro-Bio Tech, Université de Liège, Liège, Belgium

R. S. Oliveira

Departamento de Biologia Vegetal, Universidade Estadual de Campinas, Campinas, Brazil 
Scope Diversification of some lineages of campo rupestre pre-dates diversification of lowland cerrado, suggesting it may be the most ancient open vegetation in eastern South America. This vegetation comprises more than 5000 plant species, nearly $15 \%$ of Brazil's plant diversity, in an area corresponding to $0.78 \%$ of its surface. Reviewing empirical data, we scrutinise five predictions of the OCBIL theory, and show that campo rupestre is fully comparable to and remarkably convergent with both fynbos and kwongkan, and fulfills the criteria for a classic OCBIL.

Conclusions The increasing threats to campo rupestre are compromising ecosystem services and we argue for the implementation of more effective conservation and restoration strategies.

Keywords Biodiversity hotspot - Canga . Endemism . Functional ecology $\cdot$ Nutrient-impoverished soils . OCBIL theory · Plant biogeography

\section{Introduction}

Unprecedented levels of anthropogenic habitat destruction are causing species extinction, erosion of genetic diversity, and loss of ecosystem services that are vital to ecosystem functioning and human well-being. Given that biodiversity and threats are unevenly distributed across the globe (Hughes et al. 2013), and resources for conservation are limited, priority areas must be designated to preserve our natural heritage and its evolutionary potential (Myers et al. 2000). Unfortunately, ecological research has traditionally focused on forests (Parr et al. 2014; Veldman et al. 2015), with a only small representation of open vegetation in the scientific literature (Fig. 1).

Old-growth tropical grasslands have been undervalued in conservation plans, although historically under severe threats (Veldman et al. 2015), and this prevents implementation of effective conservation actions

\section{E. Schaefer}

Departamento de Solos, Universidade Federal de Viçosa, Viçosa, Brazil

\section{P. L. Viana}

Coordenação de Botânica, Museu Emílio Goeldi, Belém, Brazil

R. S. Oliveira $\cdot$ H. Lambers

School of Plant Biology, University of Western Australia, Perth, Australia (see examples in Cowling et al. 2003). We do not discuss vegetation classification and terminology in detail, because this has been done recently (Alves et al. 2014), but define campo rupestre sensu lato (or rupestrian grasslands) as a montane, grassy-shrubby, fire-prone vegetation mosaic with rocky outcrops of quartzite, sandstone or ironstone (i.e. banded ironstone formation such as itabirites and cuirasses locally known as canga) along with sandy, stony and waterlogged grasslands. Patches of transitional vegetation such as cerrado, gallery forests, and relictual hilltop forests also occur within the campo rupestre landscape (Fig. 2). Campo rupestre sensu stricto can be defined as grassland mosaic and associated vegetation on the rocky outcrops. For conservation purposes, it is inappropriate to exclude woodlands immersed in campo rupestre, but our focus here is on the campo rupestre sensu stricto.

During the past few decades, there has been a significant increase in our understanding of the ecological and evolutionary processes and patterns of the campo rupestre (e.g. Stannard et al. 1995), and given their current lack of legal protection, the time is ripe for a review. Here, we present a broad overview on the ecology and evolution of campo rupestre, irreplaceable threatened and megadiverse vegetation. We focus on key issues that are important for the general understanding of this particular vegetation, including its historical geo-climatic context, and review data on plant biogeography, functional ecology, and interspecific interactions. Finally, we discuss challenges for conservation and restoration.

Here, we scrutinise five predictions of the OCBIL theory (Hopper 2009), using empirical quantitative data wherever possible: 1) predominance of species with reduced dispersability, increased local endemism and common rarity; 2) predominance of old lineages and old individuals; 3 ) the James effect (i.e. strategies for conservation of heterozygosity in the face of inbreeding due to small population size); 4) nutritional and other biological specialisations for resource acquisition, and; 5) high vulnerability to soil removal. The OCBIL theory aims to integrate hypotheses to explain plant ecology and diversity in old climatically-buffered infertile landscapes (OCBILs). Climatic stability and infertile soils are the basis of Hopper's hypotheses to explain vegetation richness and endemism. The main OCBILs identified by Hopper are the kwongkan in south-western Australia, the fynbos in south-western South Africa, and the tepuis on the Guyana shield in northern South 


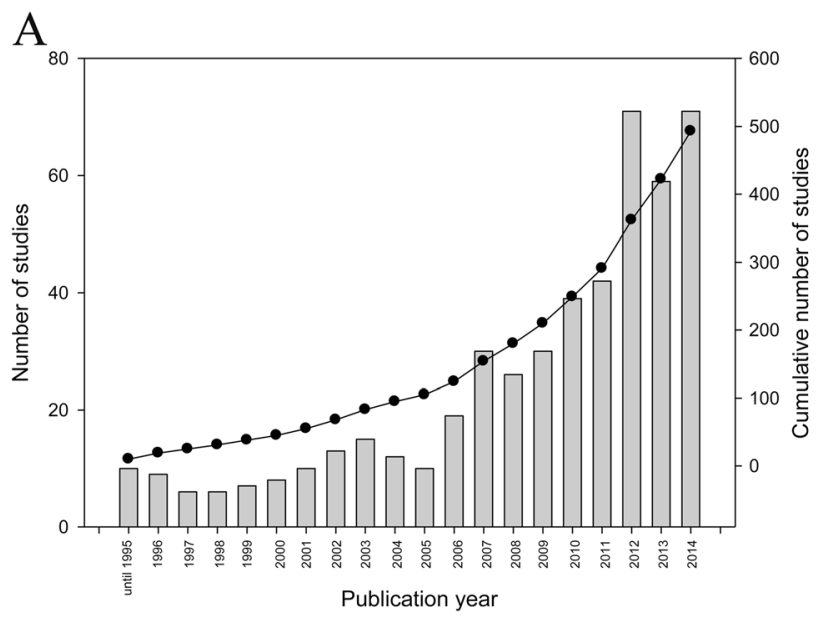

Fig. 1 Number of publications per year indexed on Web of Science, Scopus and Scielo databases searched for campo rupestre, canga, ironstone outcrops, rocky fields, rocky outrcrops, rupestrian fields, rupestrian grasslands, altitudinal rocky fields, Serra do Cipó (a). Duplicates among databases were excluded. The right axis in (a) shows the cumulative number of studies until 2014. Frequency of distribution of studies according to research area categories (b) 1 : Plant Sciences, 2: Zoology, 3: Environmental Science and Ecology, 4: Biodiversity and Conservation, 5: Evolutionary Biology, 6:

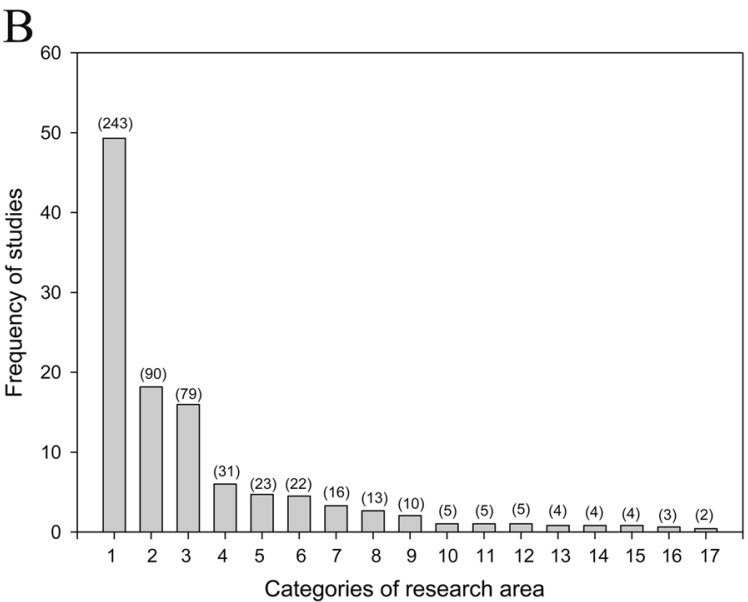

Entomology, 7: Life sciences and Biomedicine, 8: Genetics, heredity and molecular biology, 9: Forestry, 10: Parasitology and veterinary sciences, 11: Science and Technology, 12: Paleontology and Geology, 13: Mycology and Microbiology, 14: Geochemistry and Remote sensing, 15: Agriculture, 16: Pharmacology and Pharmacy, 17: Marine and Freshwater biology. Some studies were classified into more than one category according to databases. Numbers in parentheses indicate total number of studies in each category

been the focus of ecological research worldwide. Our findings are contrasted with comparable vegetation disturbed fertile landscapes (YODFELs), which have

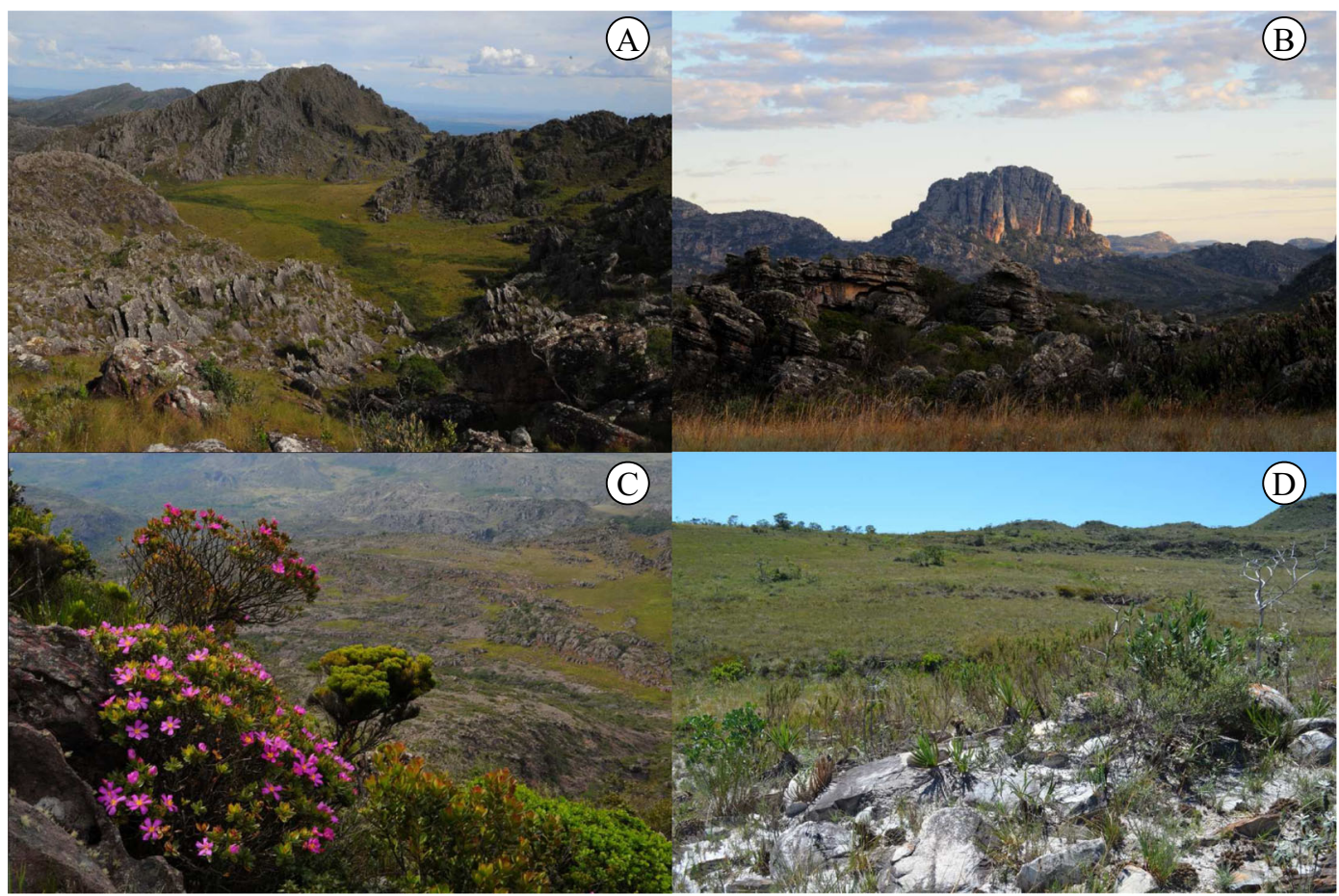

Fig. 2 Typical campo rupestre landscape in Pico das Almas (State of Bahia; a, c), Parque Nacional das SempreVivas (State of Minas Gerais; b) and Serra do Cipó (State of Minas Gerais; d). Photos a-c by Rafael S. Oliveira and D by F.A.O. Silveira 
types in the world to place our data into a global context, but specific focus is given on cross-continental comparisons with fynbos (Allsopp et al. 2014) and kwongkan (Lambers 2014).

\section{The geography, climate and soils of campo rupestre}

The total estimated area of campo rupestre sensu lato is $66,447 \mathrm{~km}^{2}$, although much of its original area has been lost due to anthropogenic activities (Fernandes et al. 2014; Fig. 3). This area corresponds to $0.78 \%$ of Brazil's continental surface. The campo rupestre is azonal vegetation with its core area resting along the highlands of the Espinhaço Range in the States of Bahia and Minas Gerais (Fig. 3). The Espinhaço Range is a $1200 \mathrm{~km}$ long mountain range, formed predominantly by Proterozoic quartzites, in eastern Brazil with maximum width ranging from 50 to $100 \mathrm{~km}$ east-west. The meridional portion of the Espinhaço Range has been classified as a Biosphere Reserve by UNESCO in 2005 to ensure adequate visibility for its conservation. The unique location of the Espinhaço Range places it at the ecotone of two global biodiversity hotspots, the Atlantic rainforest to the east and south, and the cerrado to the west. Its northern parts are bordered by the caatinga (seasonally tropical xeric shrublands and woodlands) (Giulietti et al. 1997; Hughes et al. 2013).

The campo rupestre s.s. occurs on quartzite, sandstone and ironstone formations, mostly above $900 \mathrm{~m}$ above sea level (a.s.1.) up to $2033 \mathrm{~m}$ a.s.1. Disjunct areas also occur along several mountain ranges and isolated mountains in the States of Minas Gerais, southern Bahia and eastern and north-eastern Goiás (Fig. 3). Small campo rupestre sites occur distant from the core area. These include sites in the States of Pernambuco and Paraíba, the northern-most campo rupestre areas $\left(37^{\circ} 3^{\prime} \mathrm{W} ; 9^{\circ}\right.$ $4.3^{\prime} \mathrm{S}$ ), and Mato Grosso (Frisby and Hindy 2014), the inner-most campo rupestre areas $\left(60^{\circ} 15.6^{\prime} \mathrm{W} ; 1^{\circ} 37.8^{\prime}\right.$ $\mathrm{S})$. The altitudinal grassland ecosystem on white sandy soils described by Saravia (2008) at Cerro Parabanó, eastern Bolivia is likely a small patch of campo rupestre. Ironstones are concentrated at the Iron Quadrangle, a $7200 \mathrm{~km}^{2}$ area in the south of the Espinhaço Range that represents a major mineral province in the world (Jacobi and Carmo 2011). Smaller scattered canga areas also occur throughout south-eastern, north-eastern and central-west Brazil, but a particularly important and large canga immersed within the Amazon forest $\left(50^{\circ}\right.$ $\left.21^{\prime} \mathrm{W}, 6^{\circ} 1^{\prime} \mathrm{S}\right)$ is the Carajás range, where altitudes are often below $900 \mathrm{~m}$ a.s.l.

The climatic regime in campo rupestre consists of markedly dry winters and wet summers (Fig. 3). In this respect, the campo rupestre is similar to the tepuis, but differs from the fynbos and kwongkan, which show a typical Mediterranean climate, characterised by winter rains and a marked summer drought. Along the Espinhaço Range, total rainfall decreases towards the north, and mean monthly temperatures decrease towards the south (Fig. 3). It has been suggested that past climate changes may have been insufficient to promote significant expansion or retraction of campo rupestre (Alves and Kolbek 1994), although fossil and palaeoclimatic evidence is lacking. In agreement with the OCBIL theory, past climatic stability of campo rupestre may have favoured the existence of several areas of endemism and refugia (Collevatti et al. 2009; Bonatelli et al. 2014; Barbosa et al. 2015).

South-eastern Brazilian highlands are part of the most ancient landscapes on Earth which evolved under prolonged tectonic stability and extreme weathering. The ironstones of the Iron Quadrangle date back to $2.5 \mathrm{Ga}$, and the sedimentary rocks of the Espinhaço Range date back to the Statherian $(1.8-1.75 \mathrm{Ga})$ (Alkmim and Marshak 1998; Pedreira and De Waele 2008). Orogenesis events took place independently on several mountain ranges that host campo rupestre, but mostly are from the Precambrian, as is the case of the Espinhaço Range, which emerged during the Gondwana formation, nearly $640 \mathrm{Ma}$ (Alkmin 2012). A striking feature of the campo rupestre is the diversity of soil environments and associated vegetation mosaics, largerly determined by local topography and microenvironmental aspects. Rocky outcrops are widespread, especially on resistant lithologies, such as quartzitic and ferruginous sites (Benites et al. 2007). Under slow disintegration, soils are generally weakly developed, but extremely leached and nutrient-impoverished, making their properties strongly influenced by the acid, chemically-poor parent materials (Oliveira et al. 2015). Soil depth is variable, as a function of local topography and faulting/fracturing, with very shallow soils on steep slopes and deeper weathered soils in more stable flatter areas. Normally, rocky outcrops occur scattered amongst soil patches, or very small soil spots are formed directly on bare rock. Most soils associated with rocky 

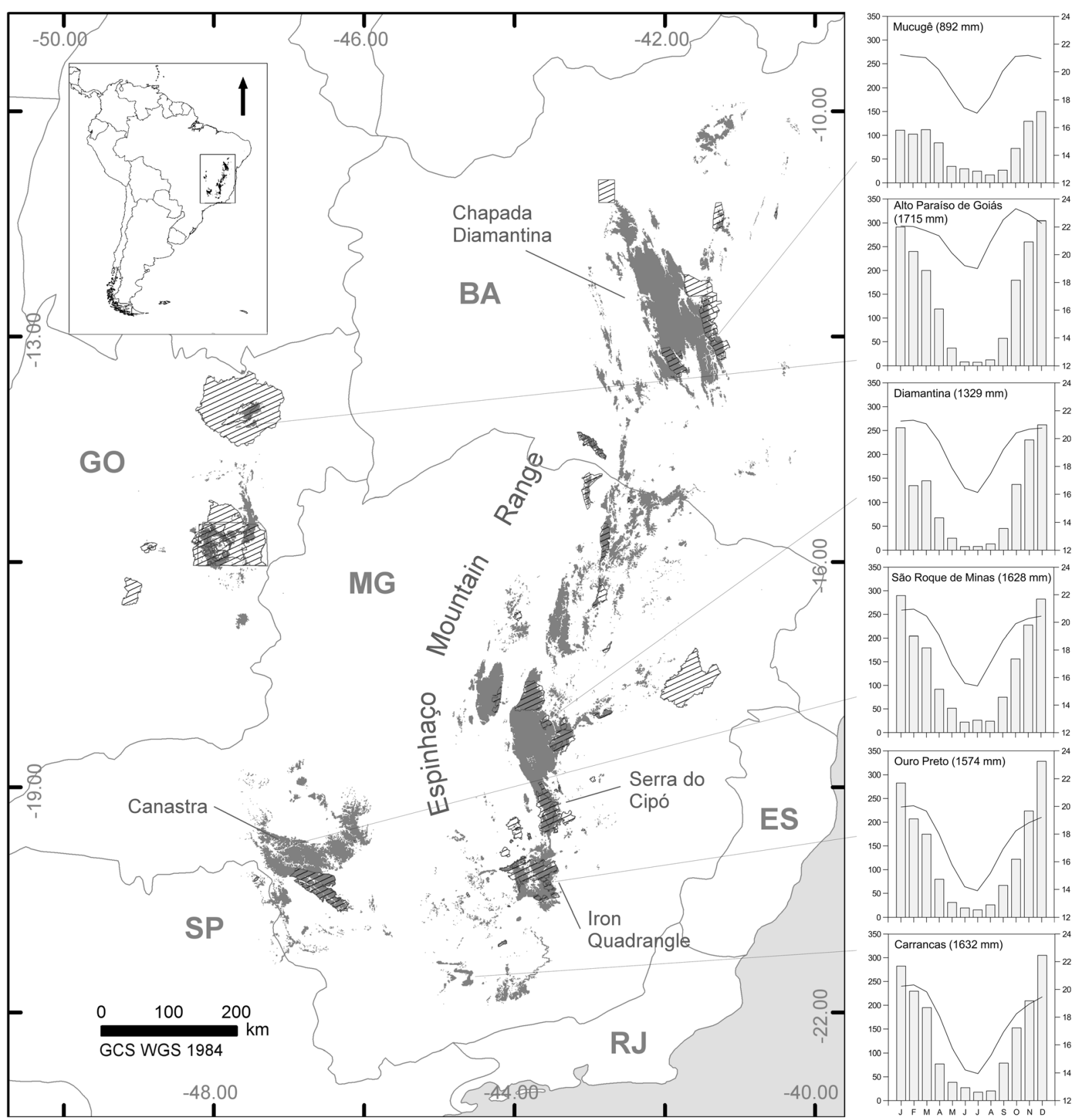

Fig. 3 Estimated predicted area of campo rupestre in Brazil resulting from the application of a binary threshold for the logistic result of a distribution model (modified from Fernandes et al. 2014). Dashed areas indicate conservation units. Right panels show climatograms (lines are temperatures, bars are rainfall and

parentheses represent total annual rainfall) of six areas forming a latitudinal climatic gradient. Abbreviations of States: $B A$ Bahia, $M G$ Minas Gerais, SP São Paulo, GO Goiás, RJ Rio de Janeiro, ES Espírito Santo

outcrops are classified as Orthents suborder of the Soil Taxonomy (USDA 1998) and as Leptosols by the FAO soil classification system (WRB 2006).

Soils in campo rupestre are derived from in-situ weathering of resistant parental material (Benites et al.
2007). When developed on quartzite and sandstone, the soils are typically shallow white sands over parent rock and have a low water-holding capacity (Appendix S1). These soils are acidic, with high aluminium (Al) saturation, and with remarkably low levels of potassium (K), 
calcium (Ca), magnesium (Mg), total exchangeable cations, and in particular plant-available phosphorus (P) (Appendix S1). Soils developed on ironstones are also shallow and acidic, with a low water-holding capacity, but exhibit lower concentrations of exchangeable $\mathrm{Al}$ and higher iron (Fe) and manganese ( $\mathrm{Mn})$ concentrations (Appendix S1).

Organic matter accumulates in soils associated with rocky outcrops due to unfavourable conditions for microbial decomposition (Benites et al. 2007). Microbial activity and decomposition rates are reduced due to the main stressing factors, an extreme oligotrophy, high $\mathrm{Al}^{3+}$ levels, and relatively low temperatures. This promotes organic carbon (C) accumulation, which favours vegetation establishment because it enhances nutrient and water retention. Additionally, mesothermic climates in campo rupestre, with cool winters can also lead to slow $\mathrm{C}$ mineralisation and high soil organic matter content.

The low nutrient status in campo rupestre soils basically results from the nutrient-poor parent rock; the range of soil fertility for campo rupestre is close to the lower detection limit for most macro nutrients. In the case of quartzite, soils are recently derived from ancient rocks, which are either weathered or physically resistant. In this sense, Schaefer (2013) emphasised the need to take into account the residual structural nature of Brazilian mountain ranges and high-altitude landforms to understand campo rupestre soil development. Despite the generally extreme and harsh characteristics of campo rupestre soils, comparisons between sites indicate that soil texture, acidity, $\mathrm{Al}^{3+}$ and $\mathrm{Ca}^{2+}$ and $\mathrm{Mg}^{2+}$ concentrations are the main factors distinguishing sites, while a secondary factor is related to concentrations of soil C, P, K and to cation exchange capacity (Fig. 4).

\section{Plant diversity, biogeography and evolution of the campo rupestre flora}

The high floristic richness of the campo rupestre is favoured by a wide altitudinal and latitudinal range, with the influence of three adjacent biomes, high soil diversity, habitat heterogeneity, and isolation among vegetation islands (Giulietti et al. 1997). The interaction of these elements throughout the climatically-stable biogeographical history of the campo rupestre favoured the persistence of old lineages that continue to diversify. The List of Species of the Brazilian Flora (LSBF 2015)

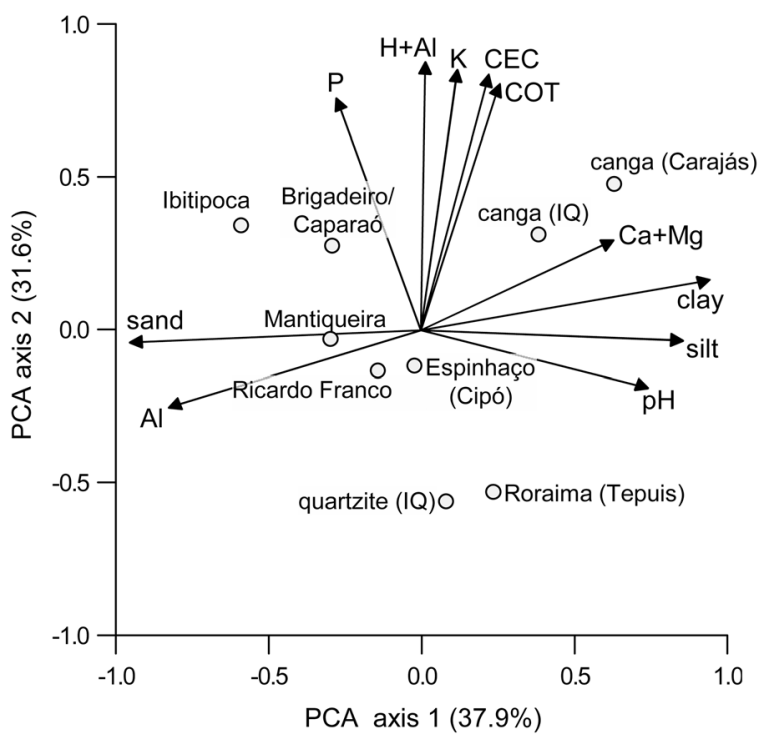

Fig. 4 Principal component analysis (PCA) on the matrix of nine sampling sites $($ circles $) \times 11$ soil parameters $($ arrows $)$ evaluated in representative types of $\mathrm{CR}$ in Brazil. Eigenvalues are indicated in brackets on each axis. $p H\left(\mathrm{H}_{2} \mathrm{O}\right)$, TOC total organic carbon $(\mathrm{g} / \mathrm{kg})$, $C E C$ cation exchange capacity $\left(\mathrm{pH} 7 ; \mathrm{cmol}_{\mathrm{c}} \mathrm{dm}^{-3}\right)$, Sand silt and clay $(\%), P\left(\mathrm{mg} \mathrm{dm}^{-3}\right), K \mathrm{Ca}+\mathrm{Mg}, \mathrm{Al}, \mathrm{H}+\mathrm{Al}\left(\mathrm{cmol}_{\mathrm{c}} \mathrm{dm}^{-3}\right)$. Variables TOC, CEC, $\mathrm{P}$ and $\mathrm{Ca}+\mathrm{Mg}$ were $\log +1$ transformed

reports 5011 native vascular plant species, in 134 families and 753 genera for the campo rupestre s.s. This richness comprises $14.7 \%$ of the entire Brazilian vascular flora in an area corresponding to only $0.78 \%$ of the country's land surface. This estimate reveals campo rupestre as the third OCBIL in terms of plant richness (Hopper 2009; Table 1). However, the definition of campo rupestre adopted by the LSBF as "altitude open fields found mostly above $900 \mathrm{~m}$ a.s.l. on quartzitic, arenitic or iron and manganese-rich rocky soils mostly associated to the Cerrado and Caatinga Biomes" fits in

Table 1 Comparison of vascular plant richness among recognized OCBILs. See Hopper (2009) for data on the other OCBILs

\begin{tabular}{lrlll}
\hline OCBIL region & $\begin{array}{l}\text { Total area } \\
\left(\mathrm{km}^{2}\right)\end{array}$ & $\begin{array}{l}\text { Species } \\
\text { richness }\end{array}$ & $\begin{array}{l}\text { Number of } \\
\text { genera }\end{array}$ & $\begin{array}{l}\text { Number of } \\
\text { families }\end{array}$ \\
\hline $\begin{array}{c}\text { Campo } \\
\text { rupestre }\end{array}$ & 66,447 & 5011 & 753 & 134 \\
$\begin{array}{l}\text { Tepui } \\
\text { Cape }\end{array}$ & 5000 & 2447 & 626 & 156 \\
$\begin{array}{c}\text { Succulent } \\
\text { karoo }\end{array}$ & 100,250 & 4849 & 730 & 118 \\
$\begin{array}{c}\text { South-western } \\
\text { Australia }\end{array}$ & 302,630 & 6759 & 711 & 143 \\
\hline
\end{tabular}


Table 2 The ten most species-rich families and genera of vascular plants in the campo rupestre and their respective number of species

\begin{tabular}{lllr}
\hline Family & Species richness & Genus & Species richness \\
\hline Asteraceae & 608 & Paepalanthus (Eriocaulaceae) & 285 \\
Fabaceae & 514 & Chamaecrista (Fabaceae) & 164 \\
Eriocaulaceae & 499 & Mimosa (Fabaceae) & 123 \\
Melastomataceae & 335 & Microlicia (Melastomataceae) & 117 \\
Orchidaceae & 275 & Vellozia (Velloziaceae) & 106 \\
Poaceae & 198 & Xyris (Xyridaceae) & 102 \\
Velloziaceae & 187 & Barbacenia (Velloziaceae) & 81 \\
Bromeliaceae & 180 & Myrcia (Myrtaceae) & 58 \\
Lamiaceae & 140 & Syngonanthus (Eriocaulaceae) & 57 \\
Rubiaceae & 120 & Habenaria (Orchidaceae) & 51 \\
Total & 3056 & Total & 1144 \\
\hline
\end{tabular}

the sensu stricto concept of campo rupestre, and therefore does not account for the woody plant formations comprised in the sensu lato concept. Moreover, this estimate is indisputably underestimated, given the increasing number of new species being described from campo rupestre (Fig. 1b; Salas et al. 2015).

At the regional scale, species density is also large; 1590 species were recorded in $200 \mathrm{~km}^{2}$ at Serra do Cipó (Giulietti et al. 1987). In the Iron Quadrangle, Jacobi and Carmo (2012) found almost 1100 species of vascular plants (60 endemics) in an area less than $4.5 \mathrm{~km}^{2}$, and Teixeira and Lemos Filho (2013) found 772 species within an area of $11.9 \mathrm{~km}^{2}$.

The ten most species-rich families and genera in the campo rupestre are shown in Table 2. Typical elements include the Gondwanan families (e.g. Mello-Silva et al. 2011): Eriocaulaceae, Velloziaceae and Xyridaceae, whereas Asteraceae, Fabaceae, Melastomataceae, Orchidaceae, Poaceae, Bromeliaceae, Lamiaceae and Rubiaceae also figure among the most species-rich families. This list is similar to that for the tepui flora (Berry and Riina 2005). In Iron Quadrangle outcrops, the main families are Asteraceae, Poaceae, Orchidaceae, Melastomataceae, Cyperaceae, Rubiaceae, Fabaceae and Myrtaceae (Jacobi and Carmo 2012). The hypothesis that explains high beta diversity in both southwestern Australian and Brazilian iron geosystems is that these environments represent at the same time ancient refugia and also areas of recent speciation (Rapini et al. 2008; Gibson et al. 2010; Bitencourt and Rapini 2013).

Concerning endemism at a high taxonomic level, there is no exclusive family and only a few genera are endemic to the campo rupestre (Alves and Kolbek
2010). This lack of exclusiveness in higher taxonomic hierarchies probably relates to the discontinuity and natural fragmentation of the campo rupestre, as the older lineages come to occupy the surrounding lowland areas. In more recent lineages, however, endemics are common (Harley 1988; Bitencourt and Rapini 2013). Some taxa are extraordinarily incredibly species-rich, as can be noticed by the fact that the ten richest families account for more than $60 \%$ of the flora and the ten richest genera for more than $22 \%$ (Table 1). On the other hand, $23 \%$ of families and $39 \%$ of genera are represented by a single species. Currently there is no estimate of the proportion of endemics of the whole campo rupestre flora, but percentages are thought to be higher than that of lowland cerrado (Hughes et al. 2013). Plant communities in canga sustain approximately $6 \%$ of endemics, similar to other mainland metalliferous habitats such as the Katanga (DR Congo) copper belt and the Yilgarn ironstones in western Australia (Gibson et al. 2012; Meissner et al. 2009; Faucon et al. 2010).

Within families the proportion of endemics can be very large. Some families e.g., Eriocaulaceae, Velloziaceae and Xyridaceae have their centre of diversity in the campo rupestre. Endemism rates are $70 \%$ for the Velloziaceae in the Minas Gerais portion of the Espinhaço Range (Mello-Silva 1989). Within Eriocaulaceae, $35-45 \%$ of all species occur in campo rupestre, and of these probably $60-80 \%$ are endemic (Giulietti et al. 1987, 1997; Costa et al. 2008). Nearly $84 \%$ of the diversity of Paepalanthus (Eriocaulaceae), the richest genus of Brazil (Forzza et al. 2010) is found in campo rupestre, with several endemic infrageneric taxa. A significant portion of the campo rupestre species 
is narrow endemic, i.e. they occur on a single mountain, or part of a mountain, and sometimes they are known from just a single population. As a result, several taxa are known only from the type collection or type locality. Paepalanthus subg. Xeractis comprises 28 species, all restricted to campo rupestre in the meridional Espinhaço Range: 18 species are known from a single locality and six are known only from the type collection (Hensold 1988; Echternacht et al. 2011a). Some of those taxa are possibly extinct (Mendonça and Lins 2000), but thorough surveys might lead to rediscoveries (e.g. Echternacht et al. 2010).

The campo rupestre is amongst the most biologically diverse ecosystems in the world. However, because sampling effort is heterogeneous and large areas are still virtually uncovered (Madeira et al. 2008), knowledge on plant diversity and biogeography relies on locally-restricted surveys and floras (see Rapini et al. 2008). New species are described continuously, as exemplified by Eriocaulaceae, in which 30 new species were described in the last 10 years, 27 from campo rupestre, and all of them are threatened with extinction according to the IUCN (2011) criteria. The ongoing project Red List by CNCFlora (the IUCN authority in Brazil) aims to evaluate conservation status of all species of the Brazilian flora by 2020; given the nature of this task, it is being performed in subprojects (e.g. Martinelli and Moraes 2013), but most campo rupestre species have not yet been evaluated (CNCFlora 2015).

The endemism in campo rupestre is not randomly distributed, but rather geographically structured (Hughes et al. 2013). Areas of endemism suggest that vicariance played an important role in diversification (Echternacht et al. 2011b). The campo rupestre is an ecosystem intrinsically delimited by altitude, and depressions on the relief which might represent barriers to gene flow (Lousada et al. 2011; Leles et al. 2015), promoting local speciation due to the inherent insular properties and probably due to limited dispersability. Narrow endemics with congruent distributions allow the delimitation of small areas of endemism. These narrow endemics are found sympatrically with more widespread species, suggesting the historical existence of larger areas (Collevatti et al. 2009). For example, there are endemic species distributed from the Espinhaço Range to the mountains towards the centre of Brazil in Goiás (Feres et al. 2009). At a more inclusive level, the Espinhaço Range is geographically divided into two major units: the northern, encompassing interior Bahia, and the southern, in Minas Gerais, a division supported by the disjunct diversification of several plant lineages (Bitencourt and Rapini 2013; Souza et al. 2013; Echternacht et al. 2014). Moreover, within the Espinhaço subunits, there are several smaller areas of endemism (Echternacht et al. 2011b). Thus, endemic distributions occur at several scales, providing a hierarchy to the endemism areas.

While the distribution of endemics enables biogeographic inferences within the campo rupestre, shared distributions with other Neotropical environments help to understand their common origin and influences. The herbaceous monocot stratum of the campo rupestre is usually dominated by endemic species in Poaceae, Eriocaulaceae, Rapateaceae, Velloziaceae, Xyris (Xyridaceae), and Lagenocarpus (Cyperaceae) (Le Stradic et al. 2015a). Disjunctions in these taxa with the tepui flora and physiographical analysis suggest a previous biogeographical connection (Rull 2004; Huber 2006). Phylogenetic hypotheses within Eriocaulaceae show the tepui taxa as diverging early compared with campo rupestre taxa (Trovó et al. 2012; Echternacht et al. 2014). However, tepui and campo rupestre are not grouped based on shared genera, and appear to have distinct floristic influences (Alves and Kolbek 2010). Other relevant open habitats, adjacent to campo rupestre, are the rupestrian ecosystems of igneous formations called campo de altitude (altitudinal grassland) that occur mostly on the Mantiqueira and Serra do Mar ranges in south-eastern Brazil. In spite of a similar formation and common elements with campo rupestre, campo de altitude is distinct in its geological formation (Benites et al. 2007; Alves and Kolbek 2010), and has higher floristic affinities with the páramos vegetation in the Andes (Safford 2007).

The flora of the campo rupestre comprises a mosaic of species with different adaptations and multiple biogeographic origins. To date, limited data are available to assess the extent to which campo rupestre lineages are derived from cerrado species or vice versa. Available evidence, although scarce, suggests that diversification of some campo rupestre lineages pre-dates diversification of cerrado lineages by several million years (Hughes et al. 2013), providing a clue that the campo rupestre was the first open habitat in eastern South America, followed later by the cerrado. However, meta-analyses of molecular dating in other lineages are needed to support this contention. Endemic species of Bromeliaceae (Alcantarea and Vriesea), mostly rupicolous bromeliads, seem to have settled in the campo rupestre from Atlantic rainforest ancestors multiple 
times (Versieux et al. 2012), as also suggested by the predominantly rupicolous Hoffmannseggella (Orchidaceae), which is believed to have colonised the campo rupestre in the Late Miocene, around 11 Mya, before the diversification of lowland cerrado clades (Gustafsson et al. 2010). Calliandra sect. Monticola (Fabaceae), which comprises endemics to the Espinhaço Range, is a genus that probably originated in seasonallydry tropical forest habitats (Souza et al. 2013). Simon et al. (2009) estimated 10 Mya for the initial diversification of Microlicieae (Melastomataceae) with several campo rupestre endemics, implying an adaptive shift from mesic to seasonally-dry habitats during the early evolution of this group.

Dated phylogenies of unrelated endemic lineages of campo rupestre suggest an ancient origin and recent radiation and diversification (Simon et al. 2009; Trovó et al. 2012; Bitencourt and Rapini 2013; Hughes et al. 2013; Souza et al. 2013; Bonatelli et al. 2014), in accordance with the OCBIL theory. Time estimates of massive diversification events of these groups concentrate in lateMiocene, but range from 10 Mya to 2 Mya, suggesting continuous, recurrent events of colonisation until the early-Pleistocene. This pattern coincides with the radiation and dominance of flammable $\mathrm{C}_{4}$ grasses in savannahs worldwide following a drying climate (Beerling and Osborne 2006). Because most campo rupestre is surrounded by savannahs, the recent dominance of flammable $\mathrm{C}_{4}$ grasses (Simon et al. 2009) may have been an important agent for speciation.

Additional evidence from niche modelling, dated phylogenies and comparative phylogeography of the campo rupestre flora is required to better explore the contention that the campo rupestre acted as interglacial refugia (Bonatelli et al. 2014; Barbosa et al. 2015), as was the case for the tepuis (Rull 2005). Better support for the refugia model opens the possibility to test the hypothesis that, similarly to the tepuis, campo rupestre could have acted as a 'biodiversity pump' for the surrounding inner lowlands, due to the repeated speciation and further spreading events, as a response to past climatic fluctuations (Rull 2005; see also Simon et al. 2009).

\section{Campo rupestre vegetation: spatial heterogeneity, life-forms, regeneration and fire}

Comprising a mosaic of grasslands, bogs, gallery forests and rocky outcrops, landscape heterogeneity is a defining trait of campo rupestre (Giulietti et al. 1997). Consequently, plant populations are often spatially constrained by the landscape, with most species having very narrow ranges and patchy distributions (Echternacht et al. 2011b) - a pattern common to OCBILs (Yates et al. 2007). The geomorphological heterogeneity of the campo rupestre determines a vast spectrum of microhabitats, such as forest islands, caves, rock pools, bare rock, monocot mats, ephemeral ponds, and fissures (Conceição and Pirani 2005; Conceição et al. 2007b; Jacobi et al. 2007; Carmo and Jacobi 2012). Cavities, fissures, and connecting microchannels allow the development of unusually large root systems in ironstones, sometimes resulting in extraordinary hanging structures (Carmo and Jacobi 2013).

The campo rupestre physiognomy is similar to that of other OCBILs, with the occurrence of sclerophyllous shrubs, ericaceous leaves, acaulescent rosettes, prostrate shrubs and herbs, erect herbs, and tussocks (Le Stradic et al. 2015a). The campo rupestre is dominated by forbs and graminoids, interspersed with evergreen sclerophyllous shrubs, while other OCBILs are better described as heathlands. The low proportion of annual species (Le Stradic et al. 2015a) is also found in fynbos (Goldblatt and Manning 2002) and kwongkan (Pignatti et al. 1993; Mucina et al. 2014). Rosettes are common in species belonging to Eriocaulaceae, Velloziaceae, Asteraceae, Apiaceae, Bromeliaceae and others (Fig. 5b). Giant rosettes of Vellozia (Velloziaceae) and Lobelia (Campanulaceae) in campo rupestre are similar to those of Senecio (Asteraceae) in afroalpine vegetation (Hedberg 1973), Espeletia (Asteraceae) in páramos (Ramsay and Oxley 1997), and Xanthorrhoea (Xanthorrhoeaceae) and Kingia (Dasypogonaceae) in kwongkan (Pignatti et al. 1993; Mucina et al. 2014). Basal rosettes of Bromeliaceae and Eriocaulaceae are conspicuous in campo rupestre, as they are in tepuis (Huber 2006), páramos (Ramsay and Oxley 1997), fynbos (Manning 2007) and kwongkan (Lambers 2014).

The main life forms in campo rupestre are hemicryptophytes, nanophanerophytes and chamaephytes (Conceição and Pirani 2005). Poaceae, Cyperaceae, Xyridaceae and Eriocaulaceae dominate sandy and stony grasslands and peat bogs. The nanophanerophytes (mainly Melastomataceae, Fabaceae, Asteraceae, Myrtaceae, Vochysiaceae and Clusiaceae) usually form spatially-isolated shrublands on rocky outcrops. The rocky outcrops are dominated by desiccation-tolerant chamaephytes and 


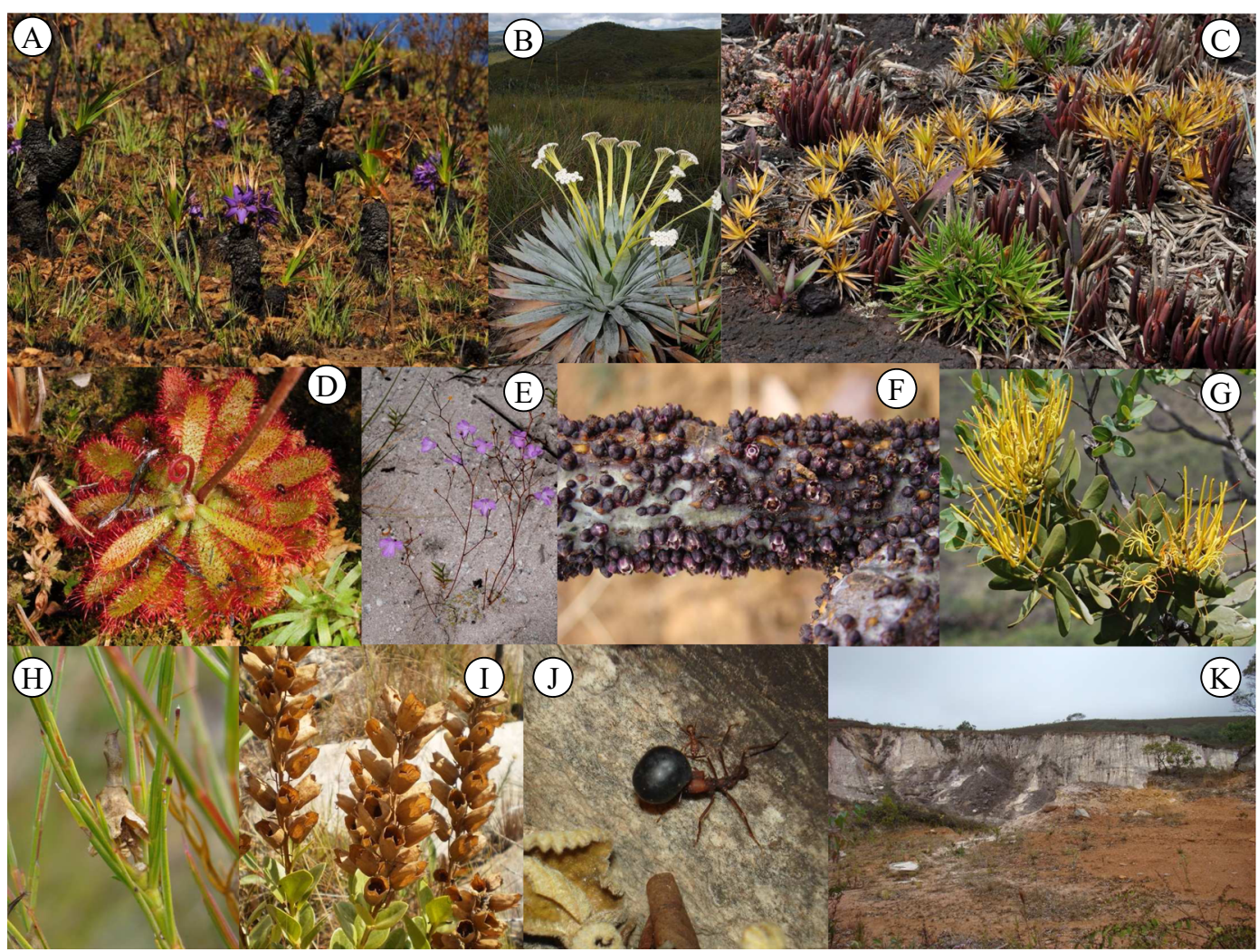

Fig. 5 Post-fire flowering of Vellozia (Velloziaceae) in the State of Minas Gerais (a). Adaptations of plants to water scarcity and lownutrient levels include rosette and rosette-like growth forms in Paepalanthus (Eriocaulaceae; b), desiccation tolerance shown by Vellozia (c), carnivory as shown in Drosera (Droseraceae; d) and Philcoxia (Plantaginaceae; e) and parasitism by Pilostyles ulei (Apodanthaceae; f). Flowers of Psittacanthus robustus (Loranthaceae), a bird-pollinated and bird-dispersed mistletoe (g).

nanophanerophytes in Sellaginellaceae, Velloziaceae and Cyperaceae, plus epilythic Orchidaceae and Bromeliaceae. Crust lichens occur on almost all rock surfaces. Cryptophytes occur in grasslands and outcrops (Amaryllidaceae and Apocynaceae), whereas conspicuous Iridaceae and Orchidaceae species occur in grasslands, where fire is a recurrent disturbance. Succulents (Cactaceae and Piperaceae) usually establish on bare rock or white sandy soils. Therophytes are inconspicuous and rare (Conceição et al. 2007b; Jacobi and Carmo 2011; Le Stradic et al. 2015a).

The vast majority of typical families from campo rupestre exhibit no obvious mechanisms for seed dispersal, so seeds are usually dispersed in close proximity to the parent plant (Ribeiro et al. unpublished data). This pattern pertains to most species in Convolvulaceae, Iridaceae, Eriocaulaceae, Xyridaceae, Velloziaceae,
Dry capsules of Lavoisiera subulata (Melastomataceae; $\mathbf{h}$ ) and the threatened hemiparasites Physocalix major (Orobanchaceae ) showing the overall pattern of unassisted seed dispersal mechanism (i). Individuals of Atta sexdens carrying a berry of Miconia irwinii (Melastomataceae; j). Poor natural regeneration in degraded campo rupestre decades after disturbance (k). Photos a-e taken by R.S. Oliveira, $\mathrm{G}$ by T. Guerra and $\mathbf{f}, \mathbf{h}-\mathbf{k}$ by F.A.O. Silveira

Microlicieae (Melastomataceae), Scrophulariaceae, Cyperaceae, and Poaceae, and in a large number of species in other families. Wind dispersal is common in species-rich families such as Orchidaceae, Asteraceae, Apocynaceae, Bignoniaceae and Bromeliaceae, while very few species produce animal-dispersed seeds such as Myrtaceae, Cactaceae, Clusiaceae, Loranthaceae (mistletoes) and Miconieae (Melastomataceae). Most zoochoric species are widespread, occurring in campo rupestre, but also in adjacent biomes.

Seed dormancy, germination, and persistence are strongly linked to climatic factors and nutrient availability after fire, and are therefore important issues to understand regeneration ecology. In other OCBILs or typical fire-prone ecosystems, research on germination ecology has focused on the role of fire-related cues in promoting germination and breaking dormancy (Keeley 
and Bond 1997; Flematti et al. 2011). So far, available evidence suggests no fire-triggered germination in campo rupestre (Le Stradic et al. 2015b). Most species from campo rupestre typically produce small non-dormant and light-demanding seeds, regardless of phylogeny (Oliveira and Garcia 2011; Cheib and Garcia 2012; Ranieri et al. 2012; Silveira et al. 2012b; Soares da Mota and Garcia 2013, but see Marques et al. 2014). Smallsized seeds have increased probabilities of burial, and thus light dependency is critical for seedling establishment (Milberg et al. 2000). In situ experimental studies testing seed longevity, important to understand vegetation recovery after disturbances, have shown that seed persistence in the soil is variable and phylogeneticallyconserved, but most species are able to build persistent soil seed banks (Gomes et al. 2001; Munné-Bosch et al. 2011; Cheib and Garcia 2012; Garcia et al. 2012, 2014; Nativel et al. 2015). Exceptions include seeds of Eremanthus (Asteraceae) (Velten and Garcia 2007), and graminoids (Le Stradic 2012), which persist in soil for less than a year. Therefore, seed bank dynamics in campo rupestre appears to be similar to that in other OCBILs, where long-term persistence has been recognised as a general pattern (Holmes and Newton 2004), but for campo rupestre it is unclear why soil seed banks have low seed density and diversity (Medina and Fernandes 2007).

Perennial species of Xyridaceae and Eriocaulaceae show annual cycles of seed dormancy (Garcia et al. 2012, 2014). The dynamics of the germination/ dormancy responses tracked with seasonal environmental conditions suggests a recurrent strategy. Seasonal dormancy cycles allow seeds to germinate immediately before periods favourable to seedling establishment (Vleeshouwers et al. 1995), so emergence seasonality would be the result of environmental conditions that favour recruitments only at certain times of the year. Indeed, physiological dormancy has evolved in species fruiting immediately after the rainy season, when soil moisture is sufficient to trigger germination, but not to allow seedling establishment (Silveira et al. 2012b). Hence, the optimum period for seed germination corresponds to a narrow window at the onset of the rainy season, when suitable environmental conditions increase the likelihood of successful seedling establishment (Garcia et al. 2012).

Like any fire-prone vegetation (Veldman et al. 2015), post-fire flowering and strongly-developed underground structures occur in some taxa of campo rupestre
(Simon et al. 2009; Conceição et al. 2013, Fig. 5a) suggesting that fire may have played a role in the evolution of regeneration traits (Simon et al. 2009). However, there are no reports on bradyspory (serotiny) in campo rupestre in contrast to the kwongkan and fynbos (Lamont et al. 1991). Despite resilience to fire (Neves and Conceição 2010), we lack sufficient data to make generalisations and further research is needed to evaluate the role of fire in the evolution of plant traits and vegetation dynamics in the campo rupestre.

Clonal reproduction is recurrent in campo rupestre (Coelho et al. 2008; Neves et al. 2014). This strategy may contribute to individual longevity. Estimated age of the oldest individuals of Vellozia kolbekii is 551 years (Alves 1994), and 3801 years for Jacaranda decurrens (Bignoniaceae), one of the oldest known living Neotropical plants (Alves et al. 2013).

\section{Functional ecology: diversity of strategies in stress-tolerant communities}

Nutritional and other biological specialisations are expected to be common in campo rupestre (Hopper 2009). Because plants from campo rupestre usually show traits related to greater resource conservation (Negreiros et al. 2014) compared with those in lowland close relatives in the Atlantic rainforest and cerrado (Lusa et al. 2014), many plant traits in the campo rupestre are thought to be adaptations to cope with high irradiance, strong winds, and the seasonal distribution of rainfall. All these filters combine with the nutrient-impoverished shallow soils with a low water-holding capacity that leads to long periods of severe water limitation for plant productivity (Lüttge et al. 2007; Morales et al. 2014, 2015; Miola and Fernandes 2015).

Resurrection (desiccation-tolerant) plants belonging to Velloziaceae are a common and abundant functional group on rocky outcrops, while non-desiccation-tolerant species are prevalent in deep, sandy soil habitats (Fig. 5c; Alcântara et al. 2015). As in kwongkan (Lambers et al. 2014a), succulents and species with Crassulacean acid metabolism (CAM) are rare. On average, only $7.1 \%$ of campo rupestre plant species are CAM plants (Lemos-Filho, unpublished data). The few CAM species in campo rupestre belong to Orchidaceae, Piperaceae, Portulacaceae, Bromeliaceae, Cactaceae and Clusiaceae, and are restricted to rocky outcrops. 
C4 grasses are dominant in campo rupestre (Garcia et al. 2009).

Given the seasonally-dry environment, one expects a plethora of functional traits related to water economy. A number of traits may play a role in this context, but further experimental evidence is required to support this contention. Many species have superficial root systems that would allow for rapid use of rain pulses (Nobel et al. 1990). Whilst leaves of resurrection plants are physiologically inactive during the dry season, they differ from deciduous species in that they retain leaf nutrients during the dry season (Griffiths et al. 2014). A recent study reported that leaves of Vellozia gigantea plants not only accumulate tocopherols, but also tocotrienols (vitamin E compounds) as antioxidants, which can protect the photosynthetic apparatus from oxidative stress especially during the dry season (Morales et al. 2014).

Aerial roots with velamen or pseudostems are common in Velloziaceae (Porembski and Barthlott 1995). In some species, the velamen might play a role in accessing moisture from dew and rain in campo rupestre (Moreira et al. 2009), but if they function like aerial roots of orchids, they are likely more important to prevent water loss than being involved in moisture or nutrient uptake (Dycus and Knudson 1957). Rosettes of bromeliads allow water retention (Nishi et al. 2013). In campo rupestre, water secretory structures and trichomes are common in several families (e.g. Lusa et al. 2014), and these structures may play a role in atmospheric water uptake (Martin and von Willert 2000). White trichomes are also common and, together with shortened internodes, they reduce the fraction of radiation that is absorbed by leaves in a wide range of phylogeneticallyunrelated species (e.g., Lusa et al. 2014).

Stomatal crypts are common in several campo rupestre dominant families (e.g. Alcântara et al. 2015). Whilst it is often claimed that stomatal crypts reduce water loss, they equally have a negative effect on $\mathrm{C}$ gain, and hence the same effect would result from stomatal closure. They are more likely important in increasing internal supply of $\mathrm{CO}_{2}$ to the chloroplasts (Lambers et al. 2014a). Xylopodia and other underground organs are common in shrubs in campo rupestre and in other OCBILs (Veldman et al. 2015). They may play a role in water storage (Lopes-Mattos et al. 2013), but also represent significant reserves of nutrients and carbohydrates, which can be utilised during resprouting after fire, extreme droughts (Neves and Conceição 2010) or herbivory. Aerenchyma occurs in roots of plants from peat bogs in campo rupestre (Coan et al. 2002).

As is common in severely P-impoverished habitats (Lambers et al. 2008, 2010), predominantly nonmycorrhizal families are relatively abundant in campo rupestre, representing $43 \%$ and $37 \%$ of the flora in sandy and stony grasslands, respectively (Fig. 6). Common nonmycorrhizal families include Cyperaceae, Xyridaceae, Eriocaulaceae, Droseraceae, Lentibulariaceae and Bromeliaceae. In kwongkan, many Cyperaceae species produce dauciform roots, which release P-mobilising carboxylates in an exudative burst (Shane et al. 2006). Similarly, non-mycorrhizal Cactaceae species from campo rupestre release carboxylates that solubilise $\mathrm{P}$ from the P-sorbing native soils (Abrahão et al. 2014). It should be noted, however, that both arbuscular mycorrhizal and ectomycorrhizal species co-occur with non-mycorrhizal species. Although campo rupestre landscapes support high diversity of arbuscular mycorrhizal fungi (de Carvalho et al. 2012), their role in plant nutrition in these severely P-impoverished soils remains largely unexplored.

Carnivory is a common alternative nutrientacquisition strategy in campo rupestre, with a wide range of trapping mechanisms as in Genlisea (Lentibulariaceae), Utricularia (Lentibulariaceae), Drosera (Droseraceae; Fig. 5d), and that of the recently-discovered underground leaves of Philcoxia (Plantaginaceae; Fig. 5e; Pereira et al. 2012). In addition, there are clear examples of protocarnivory, including rosettes of Eriocaulaceae (Nishi et al. 2013) and Bromeliaceae (Romero et al. 2006). Both hemiparasites, especially mistletoes (Lüttge et al. 1998) and holoparasites, including the remarkable Pilostyles ulei (Apodanthaceae) a specialist on Mimosa maguirei and Mimosa foliolosa (Fabaceae) (Fig. 5f), are common in campo rupestre. Pilostyles species typically parasitise legumes, also in kwongkan (Lambers et al. 2014b). A filamentous mesh-like endophyte usually grows within stems of the host (Groppo et al. 2007). Struthanthus flexicaulis (Loranthaceae) in turn, is a generalist mistletoe parasitising 44 species, frequently more than one at the same time, but with a marked incidence for Mimosa calodendron (Fabaceae) (Mourão et al. 2006). Although hemiparasites are frequently found in campo rupestre, this alternative nutrient-acquisition strategy is relatively uncommon in species-rich seasonally-dry habitats, presumably because this strategy incurs risks associated with regular droughts (Lambers et al. 2014b). 

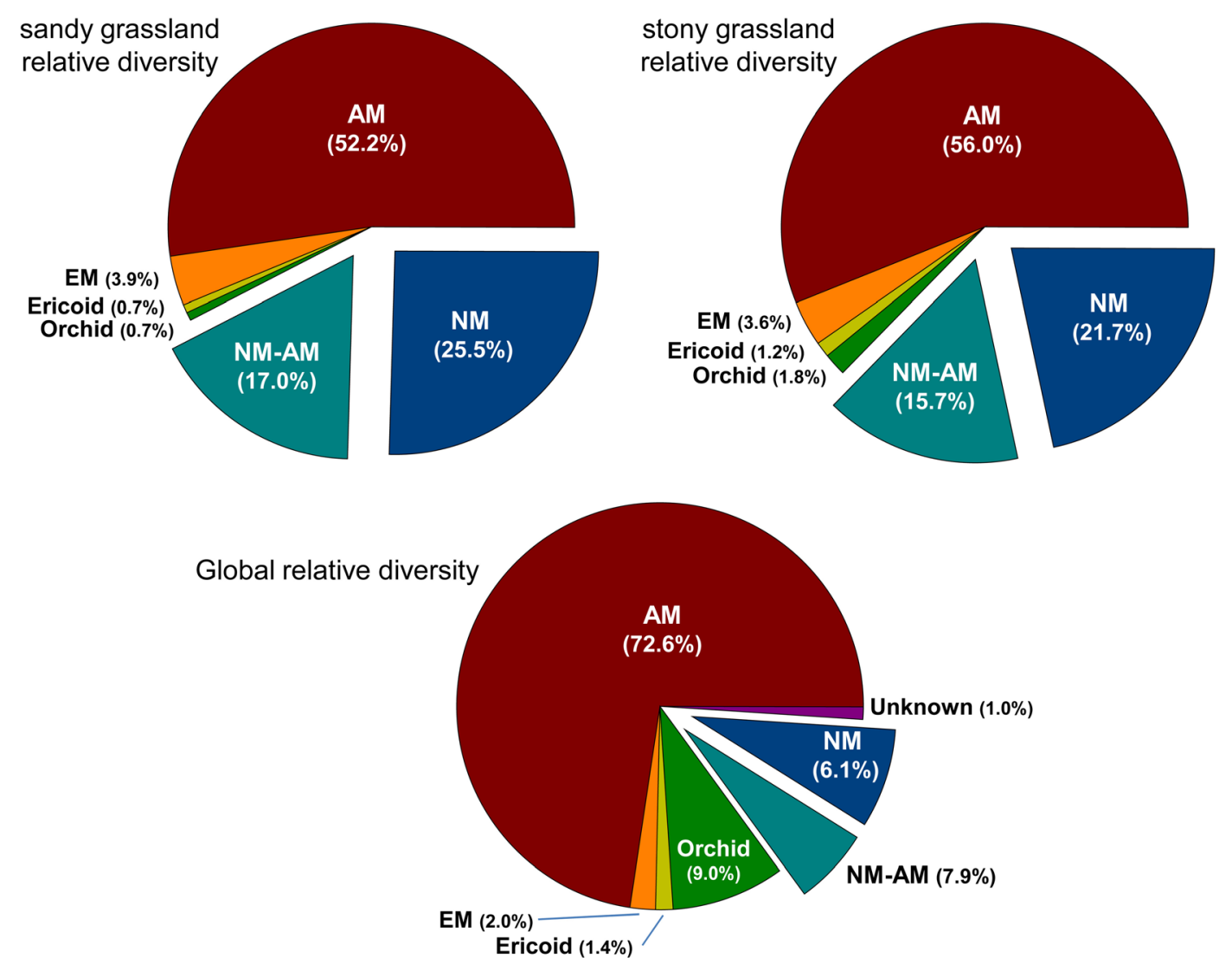

Fig. 6 Relative diversity of mycorrhizal and non-mycorrhizal species in campo rupestre (sandy and stony grasslands) of Serra do Cipó, Minas Gerais. Data for sandy and stony grasslands are from Le Stradic et al. (2015a). Global relative diversity modified from
Brundrett (2009). AM arbuscular mycorrhizal, NM nonmycorrhizal, $N M-A M$ variable NM or AM, EM ectomycorrhizal; Orchid and Ericoid are other types of mycorrhizas, confined, respectively, to the Orchidaceae and Ericaceae
Trait screening in 48 herbaceous species from campo rupestre points to a high prevalence and recurrence of stress-tolerance syndromes (Negreiros et al. 2014). The comparison with worldwide trait databases of herbaceous species highlights the extremely conservative nature of sandy and stony grassland species, which exhibit lower specific leaf area and higher leaf dry matter content compared with plants from other grasslands (Fig. 7a, b). The trait space occupied by campo rupestre species clearly reflects the 'slow' character of these communities in contrast withthe full range of the 'fastslow' plant economics spectrum (Reich 2014). Confirming this trend, recent evidence suggests that environmental stresses impose strong environmental filtering on campo rupestre vegetation (Negreiros et al. 2014), ultimately leading to convergence and/or conservatism of plant ecological strategies (Fig. 7c). On a finer scale, microhabitat variability in soil texture and water availability drives subtle, but predictable differences in plant strategies of distinct communities (Fig. 7d).

In summary, despite major differences in plant families, there is a striking similarity in the dominant functional types in campo rupestre communities and those in kwongkan and fynbos. This provides a remarkable example of functional convergence of non-mycorrhizal strategies, because most non-mycorrhizal plant families that show similarity in functional traits differ from those in Australia and South Africa. Functional convergence is clearly shown with respect to acquisition of soil and water resources (Abrahão et al. 2014; Oliveira et al. 2015). In addition to efficient resource acquisition, efficient resource use is important, and this is exhibited by slow growth, high photosynthetic nutrient-use efficiency and high leaf longevity (Lambers et al. 2014a), but some of these traits have yet to be explored in detail. 


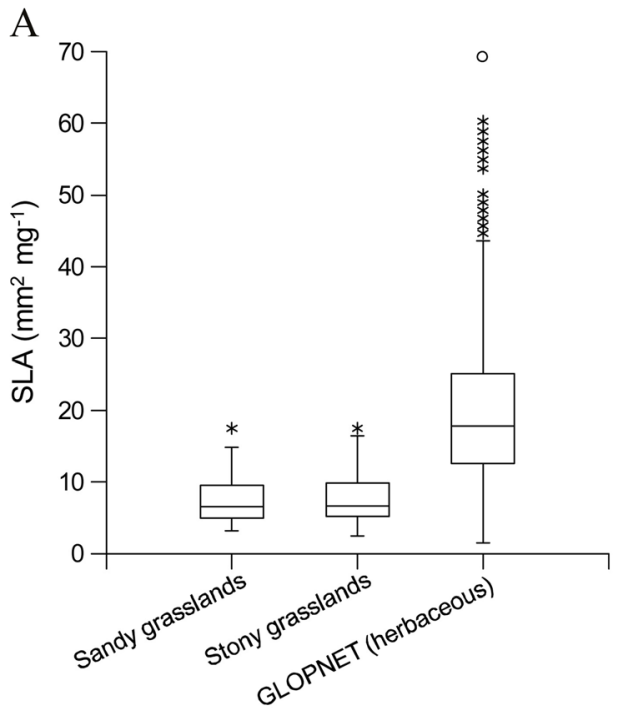

$\mathrm{C}$

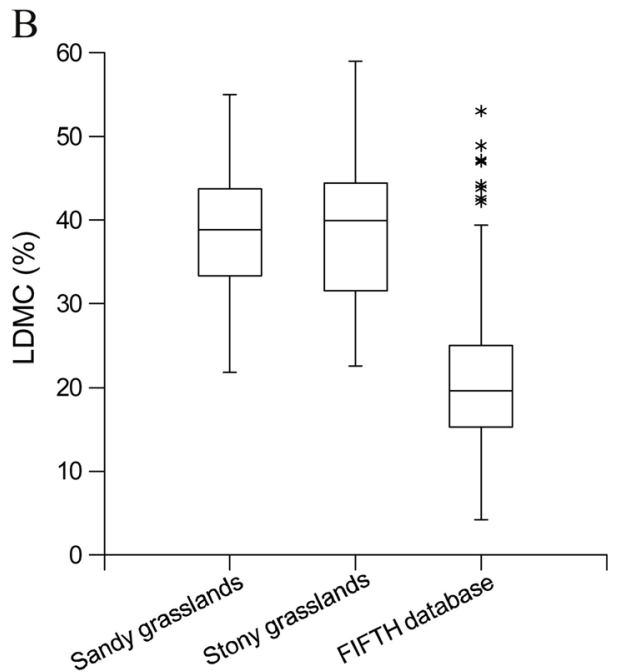

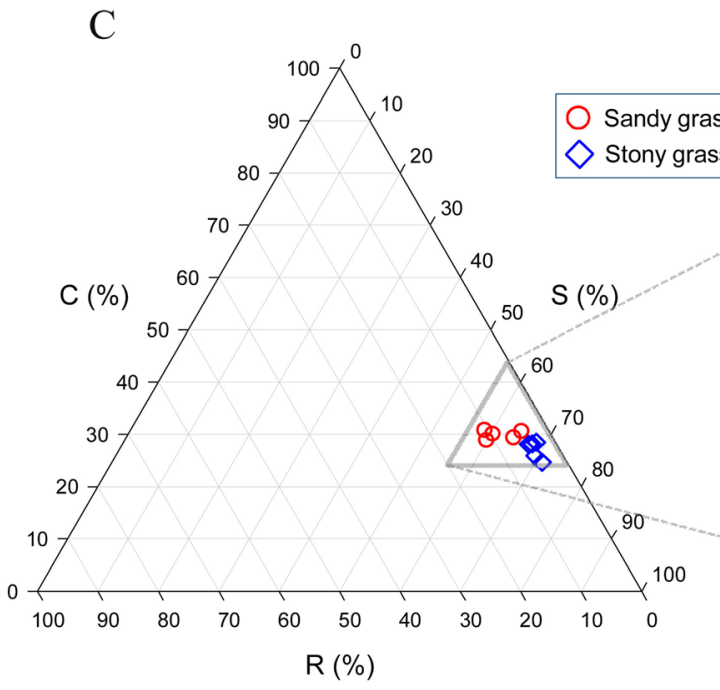

Fig. 7 Extreme resource conservation properties of herbaceous plants from campo rupestre. a Specific leaf area (SLA) of sandy and stony grasslands ( $n=42$ species each) compared with the global range of SLA values for grasses, sedges and herbs from GLOPNET database ( $n=633$ species; Wright et al. 2004); b Leaf dry matter content (LDMC) of sandy grasslands and stony grasslands compared with the range of LDMC values for grasses, sedges and herbs from FIFTH database ( $n=506$ species; Cerabolini et al. 2010); c
$\mathrm{D}$

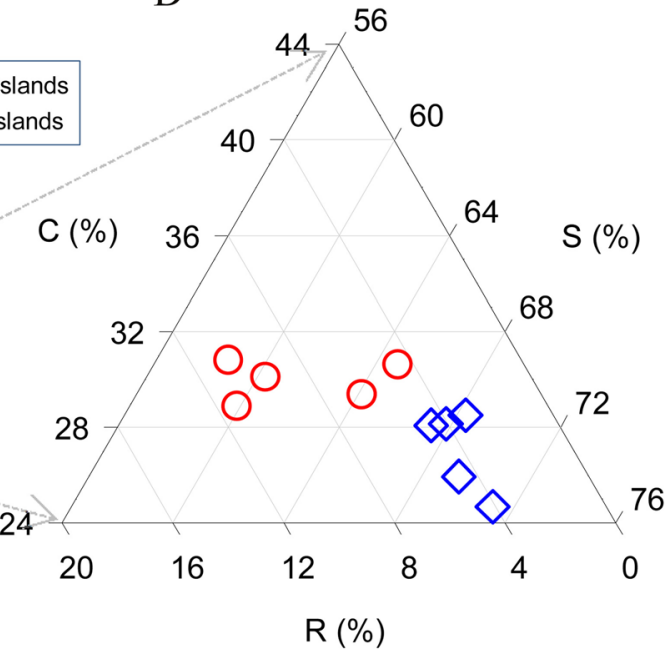

Community weighted mean (CWM based on number of ramets) percentages of C-S-R strategies (competitive, stress-tolerant and ruderal) in sandy and stony grassland communities; $\mathbf{d}$ detail showing differences in C-S-R strategies between campo rupestre communities. Symbols in panels (c) and (d) represent sites with 15 vegetation plots of $1 \times 1 \mathrm{~m}^{2}$. Data for sandy and stony grasslands are modified from Negreiros et al. (2014) and Le Stradic et al. (2015a)

\section{Plant-animal interactions}

Mutualistic plant-animal interactions

Despite the central role of mutualisms in coevolutionary processes, biodiversity maintenance and function of terrestrial ecosystems, community-level pollination and seed dispersal studies are so far practically non-existent even for otherwise well-studied OCBILs (see a brief discussion in Appendix S2). The OCBIL theory predicts the evolution of reproductive strategies that reduce inbreeding in small populations of endemic species. Seed dispersal distance should be constrained, because soil specificity should be associated with short-distance dispersal, as long-distance dispersal would incur high risks of seeds landing in unsuitable locations (Hopper 2009). 
Therefore, the main process favouring heterozygosity in campo rupestre species should be effective crosspollination by highly mobile vectors such as birds and large bees. Dioecy may also be an important trait maintaining genetic diversity among populations (Gomes et al. 2004).

If pollination is the main source of gene flow, mechanisms promoting cross-population pollination should be common. Pollination by large, long-ranging animals such as hummingbirds, bats and large bees as well as synchronised flowering phenology promoting foraging across spatially-disjunct populations are likely mechanisms ensuring long-distance outcrossing. While the adjacent cerrado or forest communities usually show $\sim 5 \%$ plants with bird-pollination syndromes, $12 \%$ of plants in campo rupestre fits the bird-pollination syndrome (Fig. 5g, Table S2). The only community-level data-set based on direct observation of plant-pollinator interactions from campo rupestre shows that $15 \%$ of the species were actually visited by hummingbirds (Carstensen et al. 2014). As in OCBILs in general, bird pollination thus seems to be important in campo rupestre and could maximise outcrossing in isolated populations, thereby providing support for the James effect prediction (Hopper 2009). However, further studies on plant population genetics are necessary to test this prediction.

The dominance of unassisted and anemochoric seed dispersal mechanisms (Fig. 5h, i) indicates that animals are more important as pollinators than as seed dispersers in campo rupestre communities (Conceição et al. 2007a; Jacobi and Carmo 2011). However, some species, including some endemics, produce ornithochorous fruits, including species in 17 families, notably Melastomataceae, Myrtaceae and Cactaceae (Conceição et al. 2007a; Faustino and Machado 2006; Silveira et al. 2012a). In tree-dominated canga depressions, zoochory becomes the prevalent syndrome (Jacobi and Carmo 2011). Unlike in tropical forests, bird communities in campo rupestre lack specialised frugivores, with the bird species feeding on fruits also eating insects to complement their diet. An example is the seed dispersal system of the mistletoe Struthanthus flexicaulis (Loranthaceae) (Guerra and Pizo 2014). The plant is locally dependent on the passerine Elaenia cristata (Tyrannidae), which disperses $96 \%$ of its seeds. Directed dispersal by birds guarantees that most seeds are deposited in suitable sites. Although birds may disperse seeds over more than $100 \mathrm{~m}$, post-feeding behaviour and short periods of seed retention in the gut cause most seeds to be deposited within $30 \mathrm{~m}$ from mother plants. In turn, the avian disperser feeds on fruits from 12 plant species as well as arthropods, with mistletoe fruits representing only $34 \%$ of its diet, indicating that mutualistic interdependence is highly asymmetrical (Guerra and Pizo 2014).

Myrmecochory is common in shrubs from sclerophyll vegetation growing on fire-prone, nutrientpoor environments in fynbos, kwongkan and the Mediterranean region (Milewski and Bond 1982). Plant traits related to seed dispersal by ants are expected to evolve in these ecosystems, as directed seed dispersal by ants includes advantages such as transport to nutrientenriched areas around their nests and seed burial, which promotes escape form superficial fires (Rico-Gray and Oliveira 2007). Yet, there is no report of primary Myrmecochory for any plant species in campo rupestre, likely because of lack of studies. Though primary myrmecochory is rare in the Neotropics, ants promote secondary seed dispersal of primarily bird-dispersed plants in campo rupestre (Lima et al. 2013; Fig. 5j). Although saurochory is considered predominantly an island phenomenon (Olesen and Valido 2004), recent reports of dispersal by lizards in campo rupestre (Fonseca et al. 2012) suggest that this mechanism of seed dispersal may also be relevant. There are no studies on seed dispersal by bats in campo rupestre. The dominance of plants with unassisted mechanisms of seed dispersal, and the relatively high importance of secondary seed dispersers (which promote short-distance seed dispersal) corroborate the predictions of the OCBIL theory regarding reduced dispersability.

Antagonistic plant-animal interactions

Studies on antagonistic interactions between animals and plants have attempted to explain the highest richness of galling insects in campo rupestre across world vegetation types. The distribution of studies amongst guilds of herbivorous insects is uneven, with galling insects representing $56 \%$ of the 27 studies so far published. A widely accepted hypothesis predicts higher richness of galling insects at intermediate latitudes, warm habitats and sclerophyllous vegetation under hygrothermal and nutritional stress (Fernandes and Price 1988), and helps to explain why OCBILs are often hotspots of galling insects (Blanche and Westoby 1995; Price et al. 1998; Veldtman and McGeoch 2003; Carneiro et al. 2009). The protection of the growing 
larvae against natural enemies in xeric habitats as well as circumvention of plant defences have been suggested as potential mechanisms explaining the adaptive radiation of galling insects in campo rupestre and other OCBILs. Host plant architecture and meristem dynamics are also linked to the mechanisms driving the diversity of gallinducing insects (Espírito-Santo et al. 2007).

\section{Threats and conservation of campo rupestre}

In eastern Brazil, early deforestation has been predominantly on flat and soil-rich lowlands, leaving the patches of nutrient-poor and montane vegetation relatively untouched. Human disturbances in campo rupestre began in the 18th century, and were first associated with mining of gold and precious stones, iron and manganese ore. Major current disturbances are opencast mining, annual anthropogenic burnings to support the cattle industry, wood extraction, and invasive species. Further threats include harvesting ornamental plants (orchids, bromeliads, everlastings (species of Syngonanthus), road construction and uncontrolled urbanisation, especially linked to tourism expansion, and eucalypt plantations, despite unsuitable soils for such purposes (Giulietti et al. 1997; Kolbek and Alves 2008; Barbosa et al. 2010).

Uncontrolled harvesting of ornamental plants to produce handicrafts has increased extinction risk in many Eriocaulaceae and Xyridaceae, and raised concerns among conservationists. In many species, early harvest may compromise species conservation as the removal of inflorescences usually happens before seed production or full maturation. Attempts to determine the best time to begin the harvest of everlasting and golden grass species aim to decrease the impact on natural populations, and at the same time provide sustainable development for the local people (Oliveira et al. 2014). Since soils at campo rupestre sites are unsuitable for cattle grazing and crop plantations, many poor people depend locally on the international market of everlasting species (Domingues et al. 2012).

Worldwide, metal-rich environments are usually home to a rare flora characterised by high percentages of species with restricted geographic distribution. Cangas comprise predominantly iron oxides, reaching levels above $80 \%$ of the total oxides, and are in the spotlight of several mining companies. These species have a unique evolutionary value, due to their adaptation to substrates with high metal concentration and shallow soils (Teixeira and Lemos-Filho 2002; Ginocchio and Baker 2004; Jacobi et al. 2007; Poot and Lambers 2008; Gibson et al. 2010). In Brazil, more than 200 rare species (Giulietti et al. 2009) occur exclusively or partially on the Fe-rich rocky outcrops (Jacobi et al. 2011). Ironstone formations constitute the predominant geological substrates for the majority of these rare species (Jacobi and Carmo 2012). Given that a species' geographic range is the most reliable predictor of extinction risk, and most species from campo rupestre are narrow endemics (Giulietti et al. 2009), it is not surprising that many of its species are threatened by extinction (Martinelli and Moraes 2013) according to the International Union for Conservation of Nature (IUCN). Opencast mining and related activities represent an extreme case of degradation of campo rupestre (Gibson et al. 2010; Jacobi et al. 2011), with no appropriate restoration strategies in place.

The Brazilian strictly-protected areas - corresponding to categories I to III in the IUCN-increased from $370,197 \mathrm{~km}^{2}$ to $520,251 \mathrm{~km}^{2}$ between 2005 and 2014 (Rylands and Brandon 2005; MMA 2014). In this same period, less than $30 \mathrm{~km}^{2}$ of natural areas that contain plant communities on ironstone outcrops were incorporated into the National Protected Areas System in the strictly-protected category. The pervasive habitat loss and a persistent lack of protection of metal-rich areas is among the main threats to rare species and could seriously impair the Brazilian commitment to Global Strategy for Plant Conservation (GSPC) goals (Jacobi et al. 2011). A recent study simulated land-use change by mining in the Iron Quadrangle by 2020 (Sonter et al. 2014). The results indicated that it is impossible to achieve a no-net loss of native vegetation for canga under a like-for-like habitat compensation rule. In that case, out-of-kind compensation (i.e. compensation with a different habitat) and re-vegetation are the only alternatives, both of which entail biodiversity loss.

A few conservation units have been created in order to protect the fragile campo rupestre. However, a specific legislation for campo rupestre is urgently required to prevent further irrecoverable biodiversity loss. Given the many tropical montane areas critically endangered by global warming mediated by topographic isolation (Rull and Vegas-Vilarrúbia 2006), and the increasing mining activities (Sonter et al. 2014), conservation actions are urgently needed to protect this endemic and threatened flora as well as associated ecosystem 
services. While threats to campo rupestre keep increasing, limited or insufficient knowledge on natural regeneration represents a serious barrier to implement effective conservation or restoration programs.

\section{Ecosystem services}

Valuation of ecosystem services is a strategic approach to biodiversity conservation and provides important data that allow decision-making to be more consistent with conservation efforts (Costanza 2006). Native plants from campo rupestre are a relevant source of natural fibres, timber, food, medicines, resins, oils and ornamentals (Stannard et al. 1995; Giulietti et al. 1997), and thus can have economic value. To estimate the value of the plant diversity in campo rupestre, Resende et al. (2013) calculated the maintenance cost of native plants in the living collections in a botanical garden to determine the annual maintenance cost of one specimen in the nursery. The acquisition and maintenance costs related to a single specimen under ex situ conditions reached US\$109.95 per individual. The storage value related to plant species with the greatest conservation value was significantly greater for endemic/threatened species compared with widespread or non-threatened species. In total, plant diversity storage value reached US\$799.11 ha year $^{-1}$. The study showed that the total value attributed to the plant diversity storage service was primarily associated with campo rupestre $(84.1 \%)$ amongst all other ecosystems evaluated (15.9\%).

Many of the most-important Brazilian watersheds have their origin within campo rupestre sites (Stannard et al. 1995). Due to high porosity, fracturing, and permeability, the ironstone constitutes vital ecosystem services to human health and environmental quality, including important areas for water storage and recharge provisioning (Carmo 2010). In the Iron Quadrangle, the exploitable underground water reserves associated with iron geosystems have been estimated at $4 \times 10^{9} \mathrm{~m}^{3}$. The median outflow measured in springs is $400 \mathrm{~m}^{3} \mathrm{day}^{-1}$, in some situations reaching $12,000 \mathrm{~m}^{3}$ day $^{-1}$ (CPRM 2004). Thousands of springs associated with iron geosystem aquifers provide water to Belo Horizonte, the sixth largest Brazilian city and fifth in gross national product. Based on the minimum mean specific flow during drought in water courses in iron formations and the household price of one litre of spring water, the value of provisioning for drinking water was estimated at US\$550 million year ${ }^{-1}$ (Carmo 2010).

The campo rupestre also provides many other important benefits to society, such as landscape for extreme sports, camping and adventure tourism. Proper valuation of these ecosystem services will strengthen conservation efforts, and could enable the payment for local communities living in those areas (Domingues et al. 2012).

\section{Restoration of campo rupestre}

The GSPC has set a goal to restore at least $15 \%$ of degraded ecosystems by 2020 (CBD 2010). While general guidelines are needed, restoration of OCBILs fundamentally differs from that of YODFELs. For example, YODFEL restoration traditionally manipulates soil fertility, whereas fertilisation in OCBIL restoration is strongly discouraged (Hopper 2009), due to the Psensitivity of many plant species (Lambers et al. 2008, 2014b). Increasing soil fertility in campo rupestre is not only ineffective in improving plant growth, but may also facilitate invasion by species from YODFELs (Negreiros et al. 2009; Barbosa et al. 2010).

Reduced dispersability, slow growth rates and the lack of appropriate knowledge on plant propagation, aggravate restoration challenges (Ilunga wa Ilunga et al. 2015). The campo rupestre communities are susceptible to anthropogenic disturbances, especially disturbance of the native soil. In areas degraded by quarrying, soils are usually highly altered (Negreiros et al. 2011), which strongly hampers spontaneous regeneration (Le Stradic et al. 2014a). Decades after disturbances, bare soil percent cover is high, and established vegetation mainly comprises ruderal species (Fig. 5k). This is explained by the dominance of the stress-tolerant strategy that is associated with low competitiveness and potentially limited dispersal ability (Negreiros et al. 2014). Many campo rupestre species reproduce vegetatively (Coelho et al. 2008), for many others reproduction phenology is supra-annual or irregular (Le Stradic 2012), and for several species seeds are empty or unviable (Dayrell 2015; Le Stradic et al. 2015b). In addition, the low investment in sexual reproduction in plants adapted to P-limited ecosystem (Fujita et al. 2014) further decreases seed pool supply.

To initiate or accelerate campo rupestre recovery, active restoration techniques, such as direct seeding or 
hay transfer, topsoil transpositions, native species transplantation, and vegetation mat transpositions may be required. Owing to the low density and diversity of seeds in campo rupestre soil seed banks (Medina and Fernandes 2007; Le Stradic 2012), regeneration from the seed bank or topsoil transfer may not be feasible. In subtropical grasslands, the bud bank may play the role of the seed bank for seedling recruitment (Fidelis et al. 2014), although this would have to be demonstrated for campo rupestre. Hay transfer from natural to degraded areas has been tested, but despite the presence of seeds in hay, the seeds did not germinate and/or environmental conditions were unsuitable for establishment (Le Stradic et al. 2014a). Vegetation mat/turf translocation was tested and allowed the establishment of a large number of campo rupestre species in degraded areas. However, the regeneration of donor sites was extremely low, and the damage almost irreversible (Le Stradic 2012). These results highlight, however, the potential to use community translocation (Bullock 1998) in circumstances when complete habitat destruction is unavoidable, as is the case for mining or quarrying. Although this remains to be demonstrated, using vegetation mats as a source of species to colonise larger degraded areas is unlikely to be efficient, because OCBILs are extremely vulnerable to superficial soil removal (Hopper 2009).

In addition to experiments carried out to restore campo rupestre communities, species translocation (from pristine to degraded areas) or transplantation projects (with nursery-grown seedlings) were also run as a means to rescue some target/rare/threatened species and to rehabilitate degraded areas (Machado et al. 2013; Rezende et al. 2013; Le Stradic et al. 2014b). Overall, some native species could establish in degraded areas, but none were able to promote the recolonisation of other native species from the surroundings (Le Stradic et al. 2014b). Other studies have highlighted the importance of arbuscular mycorrhizal fungi for the growth of woody campo rupestre species (Matias et al. 2009). The challenging task in campo rupestre restoration is to find the delicate set of conditions that allow reassembly of the native plant communities, together with deterrence of invasion by ruderal invasive species, a major threat to resource-limited communities.

\section{Conclusions}

We have reviewed key aspects related to the ecology and evolution of campo rupestre, a megadiverse area in the ecotone among three biomes. The campo rupestre harbours more than 5000 vascular plant species, $14 \%$ of the Brazilian diversity in less than $1 \%$ of the country's surface. This species number is definitely underestimated, and ongoing research suggests that including the woody component of the campo rupestre would increase vascular plant species diversity to 8000 9000 species (Echternacht et al., unpublished data). Diversification in campo rupestre appears to be a combination of old and recent diversification, but we still need dated phylogenies and comparative phylogeography studies to gain insights into the historical assembly of species diversity. These species evolved strategies to maximise gene flow via pollen among populations, but there are numerous cases where vegetative reproduction evolved, probably reflecting adaptations to local soil conditions. We have also highlighted examples of functional convergence with the flora in other OCBILs that experience the same set of abiotic stresses, but we recognise that quantitative assessments on convergence are needed. Due to low dispersability and slow growth rates, plant communities of campo rupestre are highly sensitive to soil removal.

Our data suggest the campo rupestre fulfills the criteria for a classic OCBIL and indicate climatic stability and infertile soils are key factors driving the evolution of this megadiverse flora. We found similarities across ecological scales between campo rupestre, fynbos and kwongkan, despite their distant phylogenetic histories. However, ecological knowledge on campo rupestre still lags behind that of fynbos and kwongkan, and further research is urgently needed to support conservation and restoration strategies. We argue that ecological research will progress by including campo rupestre in crosscontinental assessments with other OCBILs, and we expect our results may help identifying OCBILs in other areas, such as Madagascar, western Africa and southeastern Asia. All these vegetation types have a similar ecology and face similar conservation problems.

Estimates of the remaining conserved area and percentage of endemic species are needed to determine if campo rupestre meets the criteria for inclusion as a biodiversity hotspot (Myers et al. 2000). We argue that knowledge on vegetation changes in relation to global change drivers are required to predict how the campo 
rupestre will respond to human-induced changes. Finally, we stress that additional investigations on ecosystem services will be important for the conservation agenda of campo rupestre (Parr et al. 2014). To achieve some of these goals, multi-taxa long-term ecological research is being undertaken aiming to investigate the spatiotemporal dynamics in ecological processes in campo rupestre. We expect the recognition of campo rupestre as a global conservation priority will help generate specific legal regulations for long-term conservation and restoration of this unique and irreplaceable environment.

Acknowledgments We thank Peter Reich, Ian Wright and Simon Pierce for original data on leaf functional traits and Marcos Callisto for providing coordinates. The comments of two reviewers and RC Colwell improved early versions of the manuscript. This research was funded by Conselho Nacional de Pesquisa e Desenvolvimento (APQ-03199-13, 561883/2010-6, 311301/2011-8, 482720/2012), Fundação de Amparo à Pesquisa de Minas Gerais (APQ-04105-10, APQ-02231-12), Sao Paulo Research Foundation (2013/50155-0, 2014/01594-4), the Ministère Français des affaires étrangères et européennes (EGIDE 2009/657176K) and French Embassy / UNESP Rio Claro Chairs 2012 and 2014. We thank CAPES for granting a PVE / Ciência sem fronteiras scholarship (88881.068071/2014-01) to HL and RSO. FAOS, AAC, LPCM, JPLF, CMJ, FSN, GWF, CES, RSO, and QSG received research productivity scholarships from $\mathrm{CNPq}$.

\section{References}

Abrahão A, Lambers H, Sawaya ACHF, Mazzafera P, Oliveira RS (2014) Convergence of a specialized root trait in plants from nutrient-impoverished soils: phosphorus-acquisition strategy in a nonmycorrhizal cactus. Oecologia 176:345-355

Alcântara S, Mello-Silva R, Teodoro GS, Drequeceler K, Ackerly D, Oliveira RS (2015) Carbon assimilation and habitat segregation in resurrection plants: comparison between desiccation- and non-desiccation-tolerant species of neotropical Velloziaceae (Pandanales). Funct Ecol

Alkmim FF, Marshak S (1998) Transamazonian orogeny in the Southern São Francisco Craton Region, Minas Gerais, Brazil: evidence for Paleoproterozoic collision and collapse in the Quadrilátero Ferrífero. Precambrian Res 90:29-58

Alkmin FF (2012) Serra do Espinhaço e Chapada Diamantina. In: Hasui Y, Carneiro CDR, Almeida FFM, Bartorelli A (eds) Geologia do Brasil. Beca, São Paulo, pp 236-244

Allsopp N, Colville JF, Verboom GA (eds) (2014) Fynbos: ecology, evolution, and conservation of a megadiverse region. Oxford University Press, New York

Alves RJV (1994) Morphological age determination and longevity in some Vellozia populations in Brazil. Folia Geobot 29:5559
Alves RJV, Kolbek J (1994) Plant species endemism in savanna vegetation on table mountais (Campo Rupestre) in Brazil. Vegetatio 113:125-139

Alves RJV, Kolbek J (2010) Can campo rupestre vegetation be floristically delimited based on vascular plant genera? Plant Ecol 207:67-79

Alves RJV, Silva NG, Fernandes Júnior A, Guimarães AR (2013) Longevity of the Brazilian underground tree Jacaranda decurrens Cham. An Acad Bras Cienc 85:671-677

Alves RJV, Silva NG, Oliveira JA, Medeiros D (2014) Circumscribing campo rupestre megadiverse brazilian rocky montane savannas. Braz J Biol 74:355-362

Barbosa NPU, Fernandes GW, Carneiro MAA, Júnior LAC (2010) Distribution of non-native invasive species and soil properties in proximity to paved roads and unpaved roads in a quartzitic mountainous grassland of southeastern Brazil. Biol Invasions 12:3745-3755

Barbosa NPU, Fernandes GW, Sanchez-Azofeita A (2015) A relict species restricted to a quartzitic mountain in tropical America: an example of microrefugium? Acta Bot Bras 29: 299-309

Beerling DJ, Osborne CP (2006) The origin of the savanna biome. Glob Chang Biol 12:2023-2031

Benites VM, Schaefer CER, Simas FNB, Santos HG (2007) Soil associated with rock outcrops in the Brazilian mountain ranges Mantiqueira and Espinhaço. Rev Bras Bot 30:569577

Berry PE, Riina R (2005) Insights into the diversity of the Pantepui flora and the biogeographic complexity of the Guayana Shield. Biol Skrif 55:145-167

Bitencourt C, Rapini A (2013) Centres of endemism in the Espinhaço Range: identifying cradles and museums of Asclepiadoideae (Apocynaceae). Syst Biodivers 11:525-536

Blanche KR, Westoby M (1995) Gall-forming insect diversity is linked to soil fertility via host plant taxon. Ecology 76:2334 2337

Bonatelli IAS, Perez MF, Peterson AT, Taylor NP, Zappi DC, Machado MC, Koch I, Pires AHC, Moraes EM (2014) Interglacial microrefugia and diversification of a cactus species complex: phylogeography and palaeodistributional reconstructions for Pilosocereus aurisetus and allies. Mol Ecol 23:3044-3063

Brundrett MC (2009) Mycorrhizal associations and other means of nutrition of vascular plants: understanding the global diversity of host plants by resolving conflicting information and developing reliable means of diagnosis. Plant Soil 320:37-77

Bullock JM (1998) Community translocation in Britain: setting objectives and measuring consequences. Biol Conserv 84: 199-214

Carmo FF (2010) Importância ambiental e estado de conservação dos ecossistemas de cangas no Quadrilátero Ferrífero e proposta de áreas-alvo para a investigação e proteção da biodiversidade em Minas Gerais. Master Thesis: Universidade Federal de Minas Gerais

Carmo FF, Jacobi CM (2012) The cangas of the Iron Quadrangle. In: Jacobi CM, Carmo FF (eds) Floristic diversity of the Quadrilátero Ferrífero cangas. IDM, Belo Horizonte, pp $14-30$

Carmo FF, Jacobi CM (2013) Canga vegetation in the Iron Quadrangle, Minas Gerais: characterization and phytogeographical context. Rodriguésia 64:527-541 
Carneiro MA, Borges RAX, Araújo APA, Fernandes GW (2009) Insetos indutores de galhas da porção sul da Cadeia do Espinhaço, MG. Rev Bras Entomol 53:570-592

Carstensen DW, Sabatino M, Trojelsgaard K, Morellato LPC (2014) Beta diversity of plant-pollinator networks and the spatial turnover of pairwise interactions. PLoS One 9, e112903

CBD - Convention of Biological Diversity (2010) COP Decision $\mathrm{X} / 2$. Strategic plan for biodiversity 2011-2020. http://www. cbd.int/decision/cop/?id=12268. Accessed 20 June 2014

Cerabolini BEL, Brusa G, Ceriani RM, de Andreis R, Luzzaro A, Pierce S (2010) Can CSR classification be generally applied outside Britain? Plant Ecol 210:253-261

Cheib AL, Garcia QS (2012) Longevity and germination ecology of seeds of endemic Cactaceae species from high-altitude sites in south-eastern Brazil. Seed Sci Res 21:45-53

Coan AI, Scatena VL, Giulietti AM (2002) Anatomia de algumas espécies aquáticas de Eriocaulaceae brasileiras. Acta Bot Bras 16:371-384

Coelho FF, Capelo C, Ribeiro LC, Figueira JEC (2008) Reproductive modes in Leiothrix (Eriocaulaceae) in southeastern Brazil: the role of microenvironmental heterogeneity. Ann Bot 101:353-360

Collevatti RG, Rabelo SG, Vieira RF (2009) Phylogeography and disjunct distribution in Lychnophora ericoides (Asteraceae), an endangered cerrado shrub species. Ann Bot 104:655-664

Conceição AA, Pirani JR (2005) Delimitação de habitats em campos rupestres na Chapada Diamantina, Bahia: substratos, composição florística e aspectos estruturais. Bol Bot Univ São Paulo 23:85-111

Conceição AA, Funch LS, Pirani JR (2007a) Reproductive phenology, pollination and seed dispersal syndromes on sandstone vegetation in the "Chapada Diamantina", northeastern Brazil: population and community analyses. Rev Bras Bot 30:475-485

Conceição AA, Pirani JR, Meirelles ST (2007b) Floristics, structure and soil of insular vegetation in four quartzite-sandstone outcrops of Chapada Diamantina, northeast Brazil. Rev Bras Bot 30:641-655

Conceição AA, Alencar TG, Souza JM, Moura ADC, Silva GA (2013) Massive post-fire flowering events in a tropical mountain region of Brazil: high episodic supply of floral resources. Acta Bot Bras 27:847-850

Costa FN, Trovó M, Sano PT (2008) Eriocaulaceae na Cadeia do Espinhaço: riqueza, endemismo e ameaças. Megadiversidade 4:117-125

Costanza R (2006) Nature: ecosystems without commodifying them. Nature 443:749

Cowling RM, Pressey RL, Rouget M, Lombard AT (2003) A conservation plan for a global biodiversity hotspot - the Cape Floristic Region, South Africa. Biol Conserv 112: 191-216

CNCFlora - Centro Nacional de Conservação da Flora (2015) Projeto Lista Vermelha. http://cncflora.jbrj.gov.br/portal/ptbr/projetos/lista-vermelha. Accessed 7 July 2015

CPRM - Companhia de Pesquisas e Recursos Minerais (2004) Projeto APA Sul RMBH: hidrogeologia, mapa hidrogeológico escala 1:50.000.SEMAD/CPRM, Belo Horizonte
Dayrell RLC (2015) Ecology and evolution of seed dormancy in campos rupestres. M.Sc. Thesis. Universidade Federal de Minas Gerais

de Carvalho F, Souza FA, Carrenho R, Moreira FMS, Jesus EC, Fernandes GW (2012) The mosaic of habitats in the highaltitude Brazilian rupestrian fields is a hotspot for arbuscular mycorrhizal fungi. Appl Soil Ecol 52:9-19

Domingues SA, Karez CS, Biondini IVF, Andrade MA, Fernandes GW (2012) Economic environmental management tools in the Serra do Espinhaço Biosphere Reserve. J Sustain Dev 5:180-191

Dycus AM, Knudson L (1957) The role of the velamen of the aerial roots of orchids. Bot Gaz 119:78-87

Echternacht L, Trovó M, Sano PT (2010) Rediscoveries in Eriocaulaceae: seven narrowly distributed taxa from the Espinhaço Range in Minas Gerais, Brazil. Feddes Repert 121:117-126

Echternacht L, Sano PT, Trovó M, Dubuisson J (2011a) Phylogenetic analysis of the Brazilian microendemic Paepalanthus subgenus Xeractis (Eriocaulaceae) inferred from morphology. Bot J Linn Soc 167:137-152

Echternacht L, Trovó M, Oliveira CT, Pirani JR (2011b) Areas of endemism in the Espinhaço Range in Minas Gerais, Brazil. Flora 206:782-791

Echternacht L, Sano PT, Bonillo C, Cruaud C, Couloux A, Dubuisson J-Y (2014) Phylogeny and taxonomy of Syngonanthus and Comanthera (Eriocaulaceae): evidence from expanded sampling. Taxon 63:47-63

Espírito-Santo MM, Neves FS, Andrade-Neto FR, Fernandes GW (2007) Plant architecture and meristem dynamics as the mechanism determining the diversity of gall-inducing insects. Oecologia 153:353-364

Faucon M-P, Meersseman A, Shutcha MN, Mahy G, Luhembwe MN, Malaisse F, Meerts P (2010) Copper endemism in the Congolese flora: a database of copper affinity and conservational value of cuprophytes. Plant Ecol Evol 143:5-18

Faustino TC, Machado CG (2006) Frugivoria por aves em uma área de campo rupestre na Chapada Diamantina, BA. Ararajuba 14:137-143

Feres F, Zucchi MI, Souza AP, Amaral MCE, Bittrich V (2009) Phylogeographic studies of Brazilian "campo-rupestre" species: Wunderlichia mirabilis Riedel ex Baker (Asteraceae). Biotemas 22:17-26

Fernandes GW, Price PW (1988) Biogeographical gradients in galling species richness: tests of hypotheses. Oecologia 76: 161-167

Fernandes GW, Barbosa NPU, Negreiros D, Paglia AP (2014) Challenges for the conservation of vanishing megadiverse rupestrian grasslands. Nat Conservacao 12:162-165

Fidelis A, Appezzato-da-Glória B, Pillar VD, Pfadenhauer J (2014) Does disturbance affect bud bank size and belowground structures diversity in Brazilian subtropical grasslands? Flora 209:110-116

Flematti GR, Merritt DJ, Piggott MJ, Trengove RD, Smith SM, Dixon KW, Ghisalberti EL (2011) Burning vegetation produces cyanohydrins that liberate cyanide and promote seed germination. Nat Commun 2:360

Fonseca RBS, Funch LS, Borba EL (2012) Dispersão de sementes de Melocactus glaucescens e M. paucispinus (Cactaceae), no Município de Morro do Chapéu, Chapada Diamantina-BA. Acta Bot Bras 26:481-492 
Forzza RC, Baumgratz JFA, Bicudo CE, Carvalho AA Jr, Costa A, Costa DP, Hopkins M, Leitman PM, Lohmann LG, Maia LC, Martinelli G, Menezes M, Morim MP, Coelho MAN, Peixoto AL, Pirani JR, Prado J, Queiroz LP, Souza VC, Stehmann JR, Sylvestre LS, Walter BMT, Zappi D (2010) Catálogo de Plantas e Fungos do Brasil, vol 1. Andrea Jakobsson Estúdio. Instituto de Pesquisas Jardim Botânico do Rio de Janeiro, Rio de Janeiro

Frisby S, Hindy DJN (2014) Ichthyothere sasakiae, (Compositae: Heliantheae: Milleriinae), a new species from the Amazonian campo rupestre of northern Mato Grosso State, Brazil. Kew Bull 69:9504

Fujita Y, Venterink HO, van Bodegom PM, Douma JC, Heil GW, Holzel N, Jablonska E, Kotowski W, Okruszko T, Pawlikowski P, de Ruiter PC, Wassen MJ (2014) Low investment in sexual reproduction threatens plants adapted to phosphorus limitation. Nature 505:82-86

Garcia RJF, Longhi-Wagner HM, Pirani JR, Meirelles ST (2009) A contribution to the phytogeography of Brazilian campos: an analysis based on Poaceae. Rev Bras Bot 32: 703-713

Garcia QS, Giorni VT, Müller M, Munné-Bosch S (2012) Common and distinct responses in phytohormone and vitamin E changes during seed burial and dormancy in Xyris bialata and X. peregrina. Plant Biol 14:347-353

Garcia QS, Oliveira PG, Duarte DM (2014) Seasonal changes in germination and dormancy of buried seeds of endemic Brazilian Eriocaulaceae. Seed Sci Res 24: 113-117

Gibson N, Yates CJ, Dillon R (2010) Plant communities of the ironstone ranges of South Western Australia: hotspots for plant diversity and mineral deposits. Biodivers Conserv 19: 3951-3962

Gibson N, Meissner R, Markey AS, Thompson WA (2012) Patterns of plant diversity in ironstone ranges in arid south western Australia. J Arid Environ 77:25-31

Ginocchio R, Baker AJM (2004) Metallophytes in Latin America: a remarkable biological and genetic resource scarcely known and studied in the region. Rev Chil Hist Nat 77:185-194

Giulietti AM, Menezes NL, Pirani JR, Meguro M, Wanderley MGL (1987) Flora da Serra do Cipó: caracterização e lista das espécies. Bol Bot Univ São Paulo 9:1-151

Giulietti AM, Pirani JR, Harley RM (1997) Espinhaço Range region, eastern Brazil. In: Davis SD, Heywood VH, Herrera-Macbryde O, Villa-Lobos J, Hamilton AC (eds) Centres of plant diversity: a guide and strategy for their conservation. IUCN Publication Unit, Cambridge, pp 397404

Giulietti AM, Rapini A, Andrade MJG, Queiroz LP, Silva JMC (eds) (2009) Rare plants of Brazil. Conservation International, Belo Horizonte

Goldblatt P, Manning JC (2002) Plant diversity of Cape region of Southern Africa. Ann Mo Bot Gard 89:281-302

Gomes V, Madeira JA, Fernandes GW, LemosFilho JP (2001) Seed dormancy and germination of sympatric species of Chamaecrista (Leguminosae) in a rupestrian field. Int J Ecol Environ Sci 27:191-197

Gomes V, Collevatti RG, Silveira FAO, Fernandes GW (2004) The distribution of genetic variability in Baccharis concinna (Asteraceaea), an endemic, dioecious and threatened shrub of rupestrian fields of Brazil. Conserv Genet 5:157-165

Griffiths CA, Gaff DF, Neale AD (2014) Drying without senescence in resurrection plants. Front Plant Sci 5:36

Groppo M, Amaral MM, Ceccantini GCT (2007) Flora da Serra do Cipó, Minas Gerais: Apodanthaceae (Rafflesiaceae s.l.), e notas sobre a anatomia de Pilostyles. Bol Bot Univ São Paulo 25:81-86

Guerra TJ, Pizo MA (2014) Asymmetrical dependence between a Neotropical mistletoe and its avian seed disperser. Biotropica 46:285-293

Gustafsson ALS, Verola CF, Antonelli A (2010) Reassessing the temporal evolution of orchids with new fossils and a Bayesian relaxed clock, with implications for the diversification of the rare South American genus Hoffmannseggella (Orchidaceae: Epidendroideae). BMC Evol Biol 10:177

Harley RM (1988) Evolution and distribution of Eriope (Labiatae) and its relatives in Brazil. In: Vanzolini PE, Heyer WR (eds) Proceedings of a workshop on Neotropical distribution patterns. Academia Brasileira de Ciências, Rio de Janeiro, pp $71-121$

Hedberg O (1973) Adaptive evolution in a Tropical-Alpine environment. In: Heywood VH (ed) Taxonomy and ecology. Academic, London, pp 71-92

Hensold N (1988) Morphology and systematics of Paepalanthus subgenus Xeractis (Eriocaulaceae). Systematic Botany Monographs 23, Ann Arbor

Holmes PM, Newton RJ (2004) Patterns of seed persistence in South African fynbos. Plant Ecol 172:143-158

Hopper SD (2009) OCBIL theory: towards an integrated understanding of the evolution, ecology and conservation of biodiversity on old, climatically buffered, infertile landscapes. Plant Soil 322:49-86

Huber O (2006) Herbaceous ecosystems on the Guayana Shield, a regional overview. J Biogeogr 33:464-475

Hughes CE, Pennington RT, Antonelli A (2013) Neotropical plant evolution: assembling the big picture. Bot J Linn Soc 171:118

Ilunga wa Ilunga E, Mahy G, Piqueray J, Séleck M, Shutcha MN, Meerts P, Faucon M-P (2015) Plant functional traits as a promising tool for the ecological restoration of degraded tropical metal-rich habitats and revegetation of metal-rich bare soils: a case study in copper vegetation of Katanga, DRC. Ecol Eng 82:214-221

IUCN Standards and Petitions Subcommittee (2011) Guidelines for using the IUCN Red List categories and criteria. Version 9.0. IUCN Standards and Petitions Subcommittee

Jacobi CM, Carmo FF (2011) Life-forms, pollination and seed dispersal syndromes in plant communities on ironstone outcrops, SE Brazil. Acta Bot Bras 25:395-412

Jacobi CM, Carmo FF (2012) Diversidade florística nas cangas do Quadrilátero Ferrífero. IDM, Belo Horizonte

Jacobi CM, Carmo FF, Vincent RC, Stehmann JR (2007) Plant communities on ironstone outcrops - a diverse and endangered Brazilian ecosystem. Biodivers Conserv 16:21852200

Jacobi CM, Carmo FF, Campos IC (2011) Soaring extinction threats to endemic plants in Brazilian metal-rich regions. AMBIO 40:540-543 
Keeley JE, Bond WJ (1997) Convergent seed germination in South African fynbos and Californian chaparral. Plant Ecol 133:153-167

Kolbek J, Alves RJV (2008) Impacts of cattle, fire and wind in rocky savannas, southeastern Brazil. Acta Univ Carol Environ 22:111-130

Lambers H (ed) (2014) Plant life on the sandplains in Southwest Australia: a global biodiversity hotspot. UWA Publishing, Crawley

Lambers H, Raven JA, Shaver GR, Smith SE (2008) Plant nutrient-acquisition strategies change with soil age. Trends Ecol Evol 23:95-103

Lambers H, Brundrett MC, Raven JA, Hopper SD (2010) Plant mineral nutrition in ancient landscapes: high plant species diversity on infertile soils is linked to functional diversity for nutritional strategies. Plant Soil 334:1131

Lambers H, Colmer TD, Hassiotou F, Mitchell PM, Poot P, Shane MW, Veneklaas EJ (2014a) Carbon and water relations. In: Lambers H (ed) Plantlife on the sandplains in Southwest Australia: a global biodiversity hotspot. UWA Publishing, Crawley, pp 129-146

Lambers H, Shane MW, Laliberté E, Swarts ND, Teste FP, Zemunik G (2014b) Plant mineral nutrition. In: Lambers H (ed) Plant life on the sandplains in Southwest Australia: a global biodiversity hotspot. UWA Publishing, Crawley, pp $101-128$

Lamont BB, Le Maitre DC, Cowling RM, Enright NJ (1991) Canopy seed storage in woody plants. Bot Rev 57:277-317

Le Stradic S (2012) Composition, phenology and restoration of campos rupestres mountain grasslands, Brazil. Ph.D. Thesis.Universidade Federal de Minas Gerais

Le Stradic S, Buisson E, Fernandes GW (2014a) Restoration of Neotropical grasslands degraded by quarrying using hay transfer. Appl Veg Sci 17:482-492

Le Stradic S, Buisson E, Negreiros D, Campagne P, Fernandes GW (2014b) The role of native woody species in the restoration of campos rupestres in quarries. Appl Veg Sci 17:109120

Le Stradic S, Buisson E, Fernandes GW (2015a) Vegetation composition and structure of some Neotropical mountain grasslands in Brazil. J Mount Sci 12:864-877

Le Stradic S, Silveira FAO, Buisson E, Cazelles K, Carvalho V, Fernandes GW (2015b) Diversity of germination strategies and seed dormancy in herbaceous species of campo rupestre grasslands. Austral Ecol 40:537-546

Leles B, Chaves AV, Russo P, Batista JAN, Lovato MB (2015) Genetic structure is associated with phenotypic divergence in floral traits and reproductive investment in a high-altitude orchid from the Iron Quadrangle, southeastern Brazil. PLoS One 10, e0120645

Lima MHC, Oliveira EG, Silveira FAO (2013) Interactions between ants and non-myrmecochorous fruits in Miconia (Melastomataceae) in a Neotropical Savanna. Biotropica 45:217-223

Lopes-Mattos KLB, Azevedo AA, Soares AA, Meira RMSA (2013) Underground system of Mandevilla atroviolacea (Stadelm.) Woodson (Apocynaceae, Apocynoideae) from the Brazilian high-altitude grassland. S Afr J Bot $87: 27-33$
Lousada JM, Borba EL, Ribeiro KT, Ribeiro LC, Lovato MB (2011) Genetic structure and variability of the endemic and vulnerable Vellozia gigantea (Velloziaceae) associated with the landscape in the Espinhaço Range, in southeastern Brazil: implications for conservation. Genetica 139:431-440

LSBF - List of Species of the Brazilian Flora (2015) Rio de Janeiro Botanical Garden. http://floradobrasil.jbrj.gov.br/. Accessed 26 May 2015

Lusa MG, Appezzato-da-Glória B, Loeuille B, Bartoli G, Ciccarelli D (2014) Functional groups in Lychnophorinae (Asteraceae: Vernonieae) based on morphological and anatomical traits. Austral J Bot 62:150-163

Lüttge U, Haridasan M, Fernandes GW, Mattos EA, Trimborn P, Franco AC, Caldas LS, Zielgler H (1998) Photosynthesis of mistletoes in relation to their host at various sites of tropical Brazil. Trees 12:167-174

Lüttge U, Duarte HM, Scarano FR, Mattos EA, Cavalin PO, Franco AC, Fernandes GW (2007) Physiological ecology of photosynthesis of five sympatric species of Velloziaceae in the "campos rupestres" vegetation of Serra do Cipó, Minas Gerais, Brazil. Flora 202:637-646

Machado NADM, Leite MGP, Figueiredo MA, Kozovits AR (2013) Growing Eremanthus erythropappus in crushed laterite: a promising alternative to topsoil for bauxite-mine revegetation. J Environ Manag 129:149-156

Madeira JA, Ribeiro KT, Oliveira MJR, Paiva CL (2008) Distribuição espacial do esforço de pesquisa biológica na Serra do Cipó, Minas Gerais: subsídios ao manejo das unidades de conservação da região. Megadiversidade 4: $257-271$

Manning J (2007) Field guide to fynbos. Struik Publishers, Cape Town

Marques AR, Atman APF, Silveira FAO, Lemos-Filho JP (2014) Are seed germination and ecological breadth associated? Testing the regeneration niche hypothesis with bromeliads in a heterogeneous neotropical montane vegetation. Plant Ecol 215:517-529

Martin CE, von Willert DJ (2000) Leaf epidermal hydathodes and the ecophysiological consequences of foliar water uptake in species of Crassula from the Namib Desert in Southern Africa. Plant Biol 2:229-242

Martinelli G, Moraes MA (2013) Livro vermelho da flora do Brasil. Instituto de Pesquisas Jardim Botânico do Rio de Janeiro. Centro Nacional de Conservação da Flora, Rio de Janeiro

Matias SR, Pagano MC, Muzzi FC, Oliveira CA, Carneiro AA, Horta SN, Scotti MR (2009) Effect of rhizobia, mycorrhizal fungi and phosphate-solubilizing microorganisms in the rhizosphere of native plants used to recover an iron ore area in Brazil. Eur J Soil Biol 45:259-266

Medina MBO, Fernandes GW (2007) The potential of natural regeneration of rocky outcrop vegetation on rupestrian field soils in "Serra do Cipó", Brazil. Rev Bras Bot 30: 665-678

MMA - Ministério do Meio Ambiente (2014) Tabela consolidada das Unidades de Conservação. http://www.mma.gov.br/ cadastro_uc. Accessed 18 Nov 2014

Meissner R, Owen G, Bayliss B (2009) Flora and vegetation of banded iron formations of the Yilgarn Craton: Cashmere Downs Range. Conserv Sci West Aust 7:349-361 
Mello-Silva R (1989) Velloziaceae de Grão-Mogol, Minas Gerais, Brazil. MSc Thesis. Universidade de São Paulo

Mello-Silva R, Santos DYAC, Salatino MLF, Motta LB, Cattai MB, Sasaki D, Lovo J, Pita PB, Rocini C, Rodrigues CDN, Zarrei M, Chase MW (2011) Five vicarious genera from Gondwana: the Velloziaceae as shown by molecules and morphology. Ann Bot 108:87-102

Mendonça MP, Lins LV (2000) Lista vermelha das espécies ameaçadas de extinção da flora do estado de Minas Gerais. Fundação Biodiversitas \& Fundação Zoo-Botânica de Belo Horizonte, Belo Horizonte

Milberg P, Andersson L, Thompson K (2000) Large-seeded species are less dependent on light for germination then smallseeded ones. Seed Sci Res 10:99-104

Milewski AV, Bond WJ (1982) Convergence of myrmecochory in Mediterranean Australia and South Africa. In: Buckley RC (ed) Ant-plant interactions in Australia. Junk Press, The Hague, pp 89-98

Miola DTB, Fernandes GW (2015) Growing straight versus growing decumbent: soil quality and allometry in Syagrus glaucescens Becc. (Arecaceae), an endemic and threatened palm of the Espinhaço Mountains, Brazil. Acta Bot Bras 29: 417-424

Morales M, Garcia QS, Siqueira-Silva AI, Silva MC, MunnéBosch S (2014) Tocotrienols in Vellozia gigantea leaves: occurrence and modulation by seasonal and plant size effects. Planta 240:437-446

Morales M, Garcia QS, Munné-Bosch S (2015) Ecophysiological response to seasonal variations in water availability in the arborescent, endemic plant Vellozia gigantea. Tree Physiol 35:253-265

Moreira ASFP, Lemos-Filho JP, Zotz G, Isaias RMS (2009) Anatomy and photosynthetic parameters of roots and leaves of two shade-adapted orchids, Dichaea cogniauxiana Shltr. and Epidendrum secundum Jacq. Flora 204:604-611

Mourão FA, Carmo FF, Sousa PRA, Jacobi CM (2006) Hospedeiras de Struthanthus flexicaulis (Mart.) Mart. (Loranthaceae) em campos rupestres ferruginosos no Quadrilátero Ferrífero, Minas Gerais. Lundiana 7:103110

Mucina L, Laliberté E, Thiele KR, Dodson JR, Harvey J (2014) Biogeography of kwongan: origins, diversity, endemism, and vegetation patterns. In: Lambers $H$ (ed) Plant life on the sandplains in Southwest Australia, a global biodiversity hotspot. UWA Publishing, Crawley, pp 35-79

Munné-Bosch S, Oñate M, Oliveira PG, Garcia QS (2011) Changes in phytohormones and oxidative stress markers in buried seeds of Vellozia alata. Flora 206:704-711

Myers N, Mittermeier RA, Mittermeier CG, Fonseca GAB, Kent J (2000) Biodiversity hotspots for conservation priorities. Nature 403:853-858

Nativel N, Buisson E, Silveira FAO (2015) Seed storage-mediated dormancy alleviation in Fabaceae from campo rupestre. Acta Bot Bras 29:445-447

Negreiros D, Fernandes GW, Silveira FAO, Chalub C (2009) Seedling growth and biomass allocation of endemic and threatened shrubs of rupestrian fields. Acta Oecol 35:301310

Negreiros D, Fernandes GW, Berbara RLL, Rodarte LHO, Barbosa NPU (2011) Caracterização físico-química de solos quartzíticos degradados e áreas adjacentes de campo rupestre na Serra do Cipó, MG, Brasil. Neotrop Biol Conserv 6:156161

Negreiros D, Le Stradic S, Fernandes GW, Rennó HC (2014) CSR analysis of plant functional types in highly diverse tropical grasslands of harsh environments. Plant Ecol 215:379-388

Neves SPS, Conceição AA (2010) Campo rupestre recémqueimado na Chapada Diamantina, Bahia, Brasil: plantas de rebrota e sementes, com espécies endêmicas na rocha. Acta Bot Bras 24:697-707

Neves AC, Nogueira FB, Assis LR, Paglia AP, Bedê LC, Martins RP (2014) Reproductive allocation in rhizomatous, seminiferous, and pseudoviviparous Leiothrix (Eriocaulaceae) species. Plant Ecol 215:987-996

Nishi AH, Vasconcellos-Neto J, Romero GQ (2013) The role of multiple partners in a digestive mutualism with a protocarnivorous plant. Ann Bot 111:143-150

Nobel PS, Schulte PJ, North GB (1990) Water influx characteristics and hydraulic conductivity for roots of Agave deserti Engelm. J Exp Bot 41:409-415

Olesen JM, Valido A (2004) Lizards as pollinators and seed dispersers: an island phenomenon. Trends Ecol Evol 18: 177-181

Oliveira PG, Garcia QS (2011) Germination characteristics of Syngonanthus seeds (Eriocaulaceae) in campos rupestres vegetation in south-eastern Brazil. Seed Sci Res 21:35-41

Oliveira MNS, Cruz SM, Sousa AM, Moreira FC, Tanaka MK (2014) Implications of the harvest time on Syngonanthus nitens (Bong.) Ruhland (Eriocaulaceae) management in the state of Minas Gerais. Braz J Bot 37:95-103

Oliveira RS, Galvão HC, de Campos MCR, Eller CB, Pearse SJ, Lambers H (2015) Mineral nutrition of campos rupestres plant species on contrasting nutrient-impoverished soil types. New Phytol 205:1183-1194

Parr CL, Lehmann CER, Bond WJ, Hoffmann WA, Andersen AN (2014) Tropical grassy biomes: misunderstood, neglected, and under threat. Trends Ecol Evol 29:205-213

Pedreira AJ, De Waele B (2008) Contemporaneous evolution of the Palaeoproterozoic-Mesoproterozoic sedimentary basins of the São Francisco-Congo Craton. In: Pankhurst RJ, Trouw RAJ, Neves BBB, De Wit MJ (eds) West Gondwana: pre-cenozoiccorrelations across the South Atlantic region. Geological Society (Special Publications 294), London, pp 33-48

Pereira CG, Almenara DP, Winter CE, Fritsch PW, Lambers H, Oliveira RS (2012) Underground leaves of Philcoxia trap and digest nematodes. Proc Natl Acad Sci U S A 109:1154-1158

Pignatti E, Pignatti S, Lucchese F (1993) Plant communities of Stirling Range, Western Australia. J Veg Sci 4:477-488

Poot P, Lambers H (2008) Shallow-soil endemics: adaptive advantages and constraints of a specialized root-system morphology. New Phytol 178:371-381

Porembski S, Barthlott W (1995) On the occurrence of a velamen radicum in Cyperaceae and Velloziaceae. Nord J Bot 15:625629

Price PW, Fernandes GW, Lara ACF, Brawn J, Gerling D, Barrios H, Wright M, Ribeiro SP, Rothcliff N (1998) Global patterns in local number of insect galling species. J Biogeogr 25:581592

Ramsay PM, Oxley ERB (1997) The growth form composition of plant communities in the ecuadorian páramos. Plant Ecol 131:173-192 
Ranieri BD, Pezzini FF, Garcia QS, Chautems A, França MGC (2012) Testing the regeneration niche hypothesis with Gesneriaceae (tribe Sinningiae) in Brazil: implications for the conservation of rare species. Austral Ecol 37:125-133

Rapini A, Ribeiro PL, Lambert S, Pirani JR (2008) A flora dos campos rupestres da Cadeia do Espinhaço. Megadiversidade 4:15-23

Reich PB (2014) The world-wide 'fast-slow' plant economics spectrum: a traits manifesto. J Ecol 102:275-301

Resende FM, Fernandes GW, Coelho MS (2013) Economic valuation of plant diversity storage service provided by Brazilian rupestrian grassland ecosystems. Braz J Biol 73:709-716

Rezende LAL, Dias LE, Assis IR, Braga R, Rezende ML (2013) Restoration of ironstones outcrops degraded by iron minning activity in Minas Gerais State-Brazil. J Am Soc Min Reclam 2:151-159

Rico-Gray V, Oliveira P (2007) The ecology and evolution of antplant interactions. University of Chicago Press, Chicago

Romero GQ, Mazzafera P, Vasconcellos-Neto J, Trivelin PC (2006) Bromeliad-living spiders improve host plant nutrition and growth. Ecology 87:803-808

Rull V (2004) Is the lost world really lost? Palaeoecological insights into the origin of the peculiar flora of the Guayana Highlands. Naturwissenschaften 91:139-142

Rull V (2005) Biotic diversification in the Guayana Highlands: a proposal. J Biogeogr 32:921-927

Rull V, Vegas-Vilarrúbia T (2006) Unexpected biodiversity loss under global warmingin the neotropical Guayana Highlands: a preliminaryappraisal. Glob Chang Biol 12:1-9

Rylands AB, Brandon K (2005) Brazilian protected areas. Conserv Biol 19:612-618

Safford HD (2007) Brazilian Páramos IV. Phytogeography of the campos de altitude. J Biogeogr 17:1-22

Salas RM, Viana PL, Cabral EL, Dessein S, Janssens S (2015) Carajasia (Rubiaceae), a new and endangered genus from Carajás mountain range, Pará, Brazil. Phytotaxa 206:14-29

Saravia ESR (2008) El costo de la conservación de los bosques tropicales. PhD Thesis, Universidad Autónoma G. René Moreno, Santa Cruz

Schaefer CEGR (2013) Bases físicas da paisagem brasileira: estrutura geológica, relevo e solos. Tópicos Ciência Solo 8: $1-69$

Shane MW, Cawthray GR, Cramer MD, Kuo J, Lambers H (2006) Specialized 'dauciform' roots of Cyperaceae are structurally distinct, but functionally analogous with 'cluster' roots. Plant Cell Environ 29:1989-1999

Silveira FAO, Mafia PO, Lemos-Filho JP, Fernandes GW (2012a) Species-specific outcomes of avian gut passage on germination of Melastomataceae seeds. Plant Ecol Evol 145:350-355

Silveira FAO, Ribeiro RC, Oliveira DMT, Fernandes GW, LemosFilho JP (2012b) Evolution of physiological dormancy multiple times in Melastomataceae from Neotropical montane vegetation. Seed Sci Res 22:37-44

Simon MF, Grether R, Queiroz LP, Skema C, Pennington RT, Hughes CE (2009) Recent assembly of the Cerrado, a neotropical plant diversity hotspot, by in situ evolution of adaptations to fire. Proc Natl Acad Sci U S A 106:20359-20364

Soares da Mota LAS, Garcia QS (2013) Germination patterns and ecological characteristics of Vellozia seeds from high-altitude in South-eastern Brazil. Seed Sci Res 23:67-74
Sonter LJ, Barrett DJ, Soares-Filho BS (2014) Offsetting the impacts of mining to achieve no net loss of native vegetation. Conserv Biol 28:1068-1076

Souza ER, Lewis GP, Forest F, Schnadelbach AS, van den Berg C, Queiroz LP (2013) Phylogeny of Calliandra (Leguminosae: Mimosoideae) based on nuclear and plastid molecular markers. Taxon 62:1200-1219

Stannard BL, Harvey YB, Harley RM (eds) (1995) Flora of the Pico das Almas, Chapada Diamantina-Bahia, Brazil. Kew Royal Botanic Gardens, London

Teixeira WA, Lemos Filho JP (2013) A flórula rupestre do Pico de Itabirito, Minas Gerais, Brasil: lista das plantas vasculares. Bol Bot Univ São Paulo 31:199-230

Teixeira WA, Lemos-Filho JP (2002) Fatores edáficos e a colonização de espécies lenhosas em uma cava de mineração de ferro em Itabirito, Minas Gerais. Rev Árvore 26:25-33

Trovó M, Andrade MJG, Sano PT, Ribeiro PL, van den Berg C (2012) Molecular phylogenetics and biogeography of Neotropical Paepalanthoideae with emphasis on Brazilian Paepalanthus (Eriocaulaceae). Bot J Linn Soc 171:225-243

USDA (1998) Keys to soil taxonomy. United States Department of Agriculture, New York

Veldman JW, Buisson E, Durigan G, Fernandes GW, Le Stradic S, Mahy G, Negreiros D, Overbeck GE, Veldman RG, Zaloumis NP, Putz FE, Bond WJ (2015) Toward an oldgrowth concept for grasslands, savannas, and woodlands. Front Ecol Environ 13:154-162

Veldtman R, McGeoch MA (2003) Gall-forming insect species richness along a non-scleromorphic vegetation rainfall gradient in South Africa: the importance of plant community composition. Austral Ecol 28:1-13

Velten SB, Garcia QS (2007) Variation between three Eremanthus (Asteraceae) species in their ability to form a seed bank. Rev Bras Bot 30:713-719

Versieux LM, Barbará T, Wanderley MGL, Calvente A, Fay MF, Lexer C (2012) Molecular phylogenetics of the Brazilian giant bromeliads (Alcantarea, Bromeliaceae): implications for morphological evolution and biogeography. Mol Phylogenet Evol 64:177-189

Vleeshouwers LM, Bouwmeester HJ, Karssen CM (1995) Redefining seed dormancy: an attempt to integrate physiology and ecology. J Ecol 86:1031-1037

WRB, IUSS Working Group (2006) World reference base for soil resources 2006. World Soil Resources Reports No. 103. FAO, Rome

Wright IJ, Reich PB, Westoby M, Ackerly DD, Baruch Z, Bongers F, Cavender-Bares J, Chapin T, Cornelissen JHC, Diemer M, Flexas J, Garnier E, Groom PK, Gulias J, Hikosaka K, Lamont BB, Lee T, Lee W, Lusk C, Midgley JJ, Navas ML, Niinemets U, Oleksyn J, Osada N, Poorter H, Poot P, Prior L, Pyankov VI, Roumet C, Thomas SC, Tjoelker MG, Veneklaas EJ, Villar R (2004) The worldwide leaf economics spectrum. Nature 428:821-827

Yates CJ, Coates DJ, Elliott C, Byrne M (2007) Composition of the pollinator community, pollination and the mating system for a shrub in fragments of species rich kwongan in south-west Western Australia. Biodivers Conserv 16:1379-1395 